\title{
ILLICIT FINANCIAL FLOWS: ILLIGIT TRADE IN GOUNTERFEIT, PIRATED AND SUBSTANDARD GOODS IN GHANA
}

Karl Lallerstedt
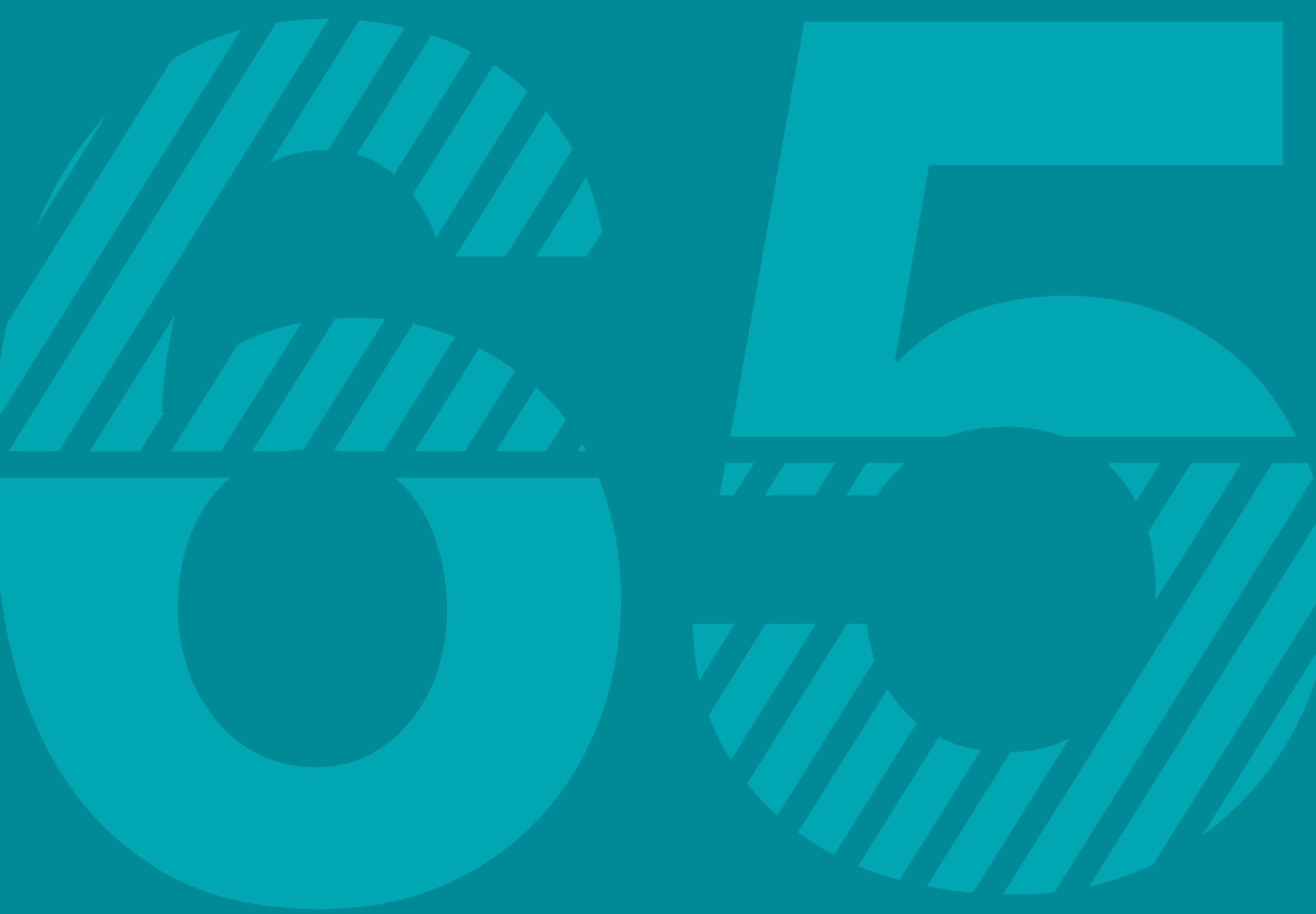

OECD DEVELOPMENT CO-OPERATION WORKING PAPER 65

Authorised for publication by Jorge Moreira da Sllva, Director, Development Co-operation Directorate 



\section{OECD Development Co-operation Working Papers}

OECD Working Papers do not represent the official views of the OECD or of its member countries. The opinions expressed and arguments employed are those of the authors.

Working Papers describe preliminary results or research in progress by the author(s) and are published to stimulate discussion on a broad range of issues on which the OECD works. Comments on the present Working Paper are welcomed and may be sent to catherine.anderson@oecd.org — the Development Cooperation Directorate, OECD, 2 rue André-Pascal, 75775 Paris Cedex 16, France.

You can copy, download or print OECD content for your own use, and you can include excerpts from OECD publications, databases and multimedia products in your own documents, presentations, blogs, websites and teaching materials, provided that suitable acknowledgement of OECD as source and copyright owner is given. All requests for public or commercial use and translation rights should be submitted to rights@oecd.org.

This document and any map included herein are without prejudice to the status of or sovereignty over any territory, to the delimitation of international frontiers and boundaries and to the name of any territory, city or area.

All groups and individuals referred to as terrorists in this report are listed in the UN sanctions regime first established by resolution 1267 on 15 October 1999 and modified by resolutions 1333 (2000), 1390 (2002), 1455 (2003), 1526 (2004), 1617 (2005), 1735 (2006), 1822 (2008), 1904 (2009), 1989 (2011), 2083 (2012) and 2161 (2014) so that sanction measures apply to individuals and entities linked to Al Qaeda as per the UN ISIL (Da'esh) \& Al Qaeda Sanctions List: https://www.un.org/securitycouncil/sanctions/un-scconsolidated-list .

Please cite this paper as: Lallerstedt, K. (2019), "Illicit financial flows: Illicit trade in counterfeit, pirated and substandard goods in Ghana", OECD Development Co-operation Working Papers, No. 65 OECD Publishing, Paris. 


\section{Abstract}

Illicit trade in goods that displace normally legal goods is an extensive global problem, which carries considerable development risks and losses for developing countries. Focusing on pharmaceuticals, agrochemicals and consumer goods (which in itself consists of a broad range of goods), this case study reviews the example of Ghana to illustrate this problem, although it is a challenge afflicting all West African countries.

This paper highlights the magnitude and significance of the problem. It also reveals the actors involved, with a view to identify the drivers and interests behind the trade, and their developmental impacts. Although the case study focuses primarily on three kinds of goods in a single country, the analysis further aims to identify common causal factors that can be extrapolated across the counterfeit, pirated and substandard trade in the wider region with a view to inform the development of prospective policy recommendations. 


\section{Acknowledgements}

The OECD report, Illicit Financial Flows: The Economy of Illicit Trade in West Africa (2018), to which this case study contributes, underlines the importance of better understanding the links between illicit financial flows (IFFs), development, and globalisation, and works to develop new ways to examine these interconnections. As such, this report contributes to a strategy of the OECD Development Co-operation Directorate to increase data and evidence in the area of IFFs to help address the risks they pose to development. As part of this approach, thirteen illicit economies were analysed, five of which were examined in detail.

This case study on illicit trade in counterfeit, pirated and substandard goods in Ghana is an important contribution to this work and constitutes one of five case studies produced by the OECD. It was authored by Karl Lallerstedt from the Global Initiative against Transnational Organised Crime. Launched under the leadership of the OECD Development Assistance Committee (DAC), through its subsidiary body the AntiCorruption Task Team (ACTT), this work was led by the OECD Secretariat, with substantive editorial support and direction by Catherine Anderson, Team Lead of Governance for Development, and Claire Naval, Policy Analyst, of the OECD Development Co-operation Directorate, Global Partnerships and Policies Division. Our thanks also go to the members of the Reference Group and to Peer Reviewers for, respectively, guiding decisions related to the choice of the case studies and providing valuable comments, inputs and expertise.

The other four IFF case studies focus on the role of AI Qaeda and its affiliates in the Islamic Maghreb; illicit narcotics transiting West Africa; human smuggling from West Africa to Europe; and the artisanal and smallscale gold-mining sector in Ghana and Liberia.

Please note that the primary research underlying this report was carried out in 2014-15. Consequently, the problems and the nature of any suggested policy responses may have since changed or evolved. Efforts have been made, where the data is available, to update the analysis and reflect current trends. 


\section{Table of contents}

OECD Development Co-operation Working Papers 3

$\begin{array}{ll}\text { Abstract } & 4\end{array}$

Acknowledgements $\quad 5$

1 Introduction 8

What is the problem? $\quad 8$

What are the negative development impacts and related challenges? 9

How is the paper structured and what issues will it address?

2 Nature and scope of illicit trade in goods that displace normally legal goods $\quad 10$

$\begin{array}{ll}\text { Falsified and substandard medication } & 10\end{array}$

$\begin{array}{ll}\text { Counterfeit and non-approved agrochemicals } & 13\end{array}$

$\begin{array}{ll}\text { Counterfeit, pirated and substandard consumer goods } & 16\end{array}$

3 Networks and actors of illicit trade $\quad 18$

Corruption networks $\quad 18$

Weak law enforcement $\quad 20$

Border controls $\quad 22$

Illicit trade at the local and international level 22

4 IFF implications and developmental impact of illicit trade in counterfeit, pirated and substandard goods 25

The challenge of measurement $\quad 25$

Threats to public health $\quad 26$

Negative economic impact $\quad 27$

Complementarities with other crimes $\quad 28$

Local problems with global implications $\quad 29$

5 Concluding remarks $\quad 30$

Quantifying the scale and impact of illicit trade 30

Economic governance 31 
Annex A. Methodology 34

References $\quad 35$

Interviews 39

Figures

Figure 2.1. Total import value of pharmaceuticals in Ghana (million USD per year) 11

Figure 2.2. Analysis of Medical Supply Samples, 2010 - 2011 (\%) 12

Figure 2.3. Ghana top three exports, 2013 ( USD millions) 14

Figure 2.4. Responses of 70 businesses selling agrochemicals ( in \%), 2015

Boxes

Box 2.1. Other illicit activities related to trade in normally legal goods 17

Box 3.1. An example of the severe damage that corruption can cause 19

$\begin{array}{ll}\text { Box 3.2. Addressing counterfeits in India } & 23\end{array}$

Box 3.3. The Chinese "Fair Wind Action" to deal with counterfeits 24

Box 3.4. The Illicit Tobacco Trade: Routes and Foreign Actors 24 


\section{Introduction}

This paper provides a broad overview of the illicit trade of counterfeit, pirated and substandard goods that displace normally legal goods. It illustrates the magnitude and significance of the problem and the actors involved, with a view to identify the drivers and interests behind the trade, and their developmental impacts. In terms of methodology, the data in this case study draws upon three pillars: desk research, interviews, and surveys of consumers and retailers (see Annex A, page 37). Through an examination of examples from three types of goods affected by this illicit trade in Ghana, the following questions will be addressed.

\section{What is the problem?}

Illicit trade in counterfeit, pirated and substandard ${ }^{1}$ goods is an extensive global problem, although compared to other forms of criminal activity, such as narcotics, human smuggling and trafficking, it receives considerably less attention, either politically or with regard to law enforcement. The shortage of reliable statistics to quantify the problem contributes to this imbalance.

For the purposes of this paper, the term "counterfeit" will consequently describe tangible goods that infringe trademarks, design rights or patents; and "pirated" will be used to describe tangible goods that infringe copyright. Also part of this study are non-counterfeit substandard goods and non-approved goods, which refer to goods that have not violated patents, trademarks etc. but that are nevertheless below the regulatory standards of given countries.

At the global level, projected figures are enormous. OECD estimates of the global trade in counterfeit and pirated goods in 2016 was estimated to be equivalent to USD 509 billion (OECD/EUIPO, 2019), up from USD 461 billion in 2013 (OECD, 2016) 2 . The trade in fake goods representing 3.3\%, and no longer $2.5 \%$, of world trade. The International Chamber of Commerce projected the value of internationally traded counterfeit and pirated goods would reach USD 770-960 billion by 2015. When including domestic production and consumption, this figure rises to USD 1 140-1 530 billion (Frontier Economics, 2011). The value of non-counterfeit substandard and non-approved goods, which are not included in these estimates but which from part of the scope of this paper, makes the total value of illicitly traded goods displacing normally legal goods even higher. To put this into comparative perspective, the United Nations Office on Drugs and Crime (UNODC) has valued the global illicit trade in narcotics at USD 320 billion, less than a third of the above figures (UNODC, 2006). These figures have been questioned. Nonetheless, it appears likely that global counterfeiting has a larger turnover than narcotics. ${ }^{3}$

These figures demonstrate that the circulation of counterfeit goods is a significant problem (Lallerstedt and Krassén, 2015), and the impact is principally local. Last year, the Director General of the Standards Organisation of Nigeria stated that over 1 million Nigerians in the textile sector had lost their jobs since 2000 due to counterfeiting (Adegoke, 2014).

Less developed economies generally suffer from a higher incidence of counterfeit, pirated and substandard goods (Lallerstedt and Krassén, 2015). This is likely both because lower income consumers demand low priced goods, and because the state's capacity to enforce regulation is often weaker than in developed 
countries. Ghana, a lower middle-income country, has a high prevalence of counterfeit, pirated and substandard goods.

Globalisation and the liberalisation of international trade have significantly increased global trade flows. The downside of this overall positive development has been increased vulnerability to the import of counterfeit, pirated and substandard goods. States with weak institutional capacity and high levels of corruption are particularly vulnerable to such illicit flows, with limited ability to monitor and control trade flows in general.

\section{What are the negative development impacts and related challenges?}

Illicit trade in goods that displace normally legal goods undermines development in a number of ways. It reduces government revenues due to smuggling, false declarations of imports and excise fraud. It further exposes legitimate economic actors to unfair competition through the wide availability of lower cost counterfeit, pirated and substandard products, thereby negatively affecting jobs and investment. It also harms public health, primarily through substandard medicines, but also through other items, such as electrical components that may be fire hazards or vehicle components that could compromise road safety. Illicit trade further weakens rule of law through corrupt payments made to public officials in customs, law enforcement, the judiciary or other government authorities which undermines border security and distorts the incentives necessary to ensure legitimate trade, legal enforcement, and effective customs border control.

Despite the scale and impact of the illicit trade in goods displacing normally legal goods, international trade laws provide limited tools to address and stem the trade in counterfeit goods (Global Initiative, 2014). Liberalised trade laws have aided trade flows. However, they have not been accompanied by the regulations needed to protect developing countries from junk imports (CAD-Analyst-220615).

\section{How is the paper structured and what issues will it address?}

Section 2 begins with a description of the nature and scope of illicit trade in goods that displace normally legal goods. Three areas of focus are expanded upon, namely i) falsified and substandard medication, ii) counterfeit and non-approved agrochemicals and iii) counterfeit and substandard consumer goods.

Section 3 lays out the networks and actors facilitating this trade. In this section, networks of corruption, weak law enforcement, and inadequate border control are all examined as facilitating factors for illicit trade in Ghana, in addition to the nexus of local and international illegal business interests.

Section 4 examines the implications of this illicit trade in counterfeit, pirated and substandard goods for illicit financial flows and development in Ghana and the region. After highlighting the measurement difficulties for this purposefully opaque illicit activity, the paper examines the threats it poses to public health, for example in relation to counterfeit medication. In addition to public health concerns, it examines two negative economic impacts and distortions of this trade, namely that it creates unfair competition and results in significant revenue losses. This section also examines the synergies of this illicit trade with other forms of crime in Ghana, for example smuggling and money laundering, and outlines the global implications that this local illicit trade poses.

Section 5 lays out concluding remarks around the case study. Following a discussion on the quantification of these forms of trade, the section lays out six potential areas that could warrant further action by both OECD and non-OECD member states. 


\section{Nature and scope of illicit trade in goods that displace normally legal goods}

Although this case study focuses primarily on the illicit trade of three kinds of normally legal goods in a single country, namely medicines, agrochemicals and consumer goods, the empirical findings of this research could be extrapolated across the wider region, where the challenge of such illicit trade is also prevalent. The presence of relatively efficient national governance structures, in the regional context, was a motivating factor for selecting Ghana for this case study. Ghana, for example, ranks in the 49th percentile of observed countries in the World Bank Worldwide Governance Indicators, and its structures may reveal insights and challenges all the more relevant in weaker more fragile contexts. It was also assumed that illicit trade may be even more extensive in other West African jurisdictions where governance indicators are weaker. Findings are based on the combined use of desk research, interviews and surveys (see Annex A: Methodology, page 41).

While the study primarily focuses on three areas of goods, the research also refers to other areas of observed phenomenon which are briefly discussed, for example the illicit trade stemming from subsidies and taxation, which create economic incentives for cross-border smuggling (see Box 2.1).

\section{Falsified and substandard medication}

The potentially lethal consequences of substandard medicines is important. It is estimated that malaria in Ghana results in more than 17000 deaths annually. In addition, the annual deaths related to HIV/AIDS are estimated at 11500 . At the same time, non-HIV related tuberculosis deaths exceed 1500 (WHO, 2014). As well as providing ineffective treatment, the prevalence of falsified and substandard medicines undermines confidence in the health sector, and substandard medicines also potentially contribute towards drug resistance (WHO, 2012).

A source with the FDA of Ghana estimated the informal sector accounts for $20-30 \%$ of direct pharmaceutical sales to consumers; such unauthorised sales are illegal. Counterfeits and unregistered products are sold in legitimate pharmacies under the counter (clearly known as illegal by the seller), as well as in cases where the retailer is probably unaware (GHA-Gov-LE-120615; GHA-INGO-Pharm-120615; GHA-Gov-LE-290515 \& 100615). Unauthorised medical sales by licensed chemical sellers are also a problem (GHA-INGO-Pharm-120615). These are concerns that have an impact beyond any country's borders, since resistant strains of diseases can easily spread. In addition to the public health implications of falsified and substandard medicines, there are also significant implications in terms of illicit financial flows. 
Figure 2.1. Total import value of pharmaceuticals in Ghana (million USD per year)

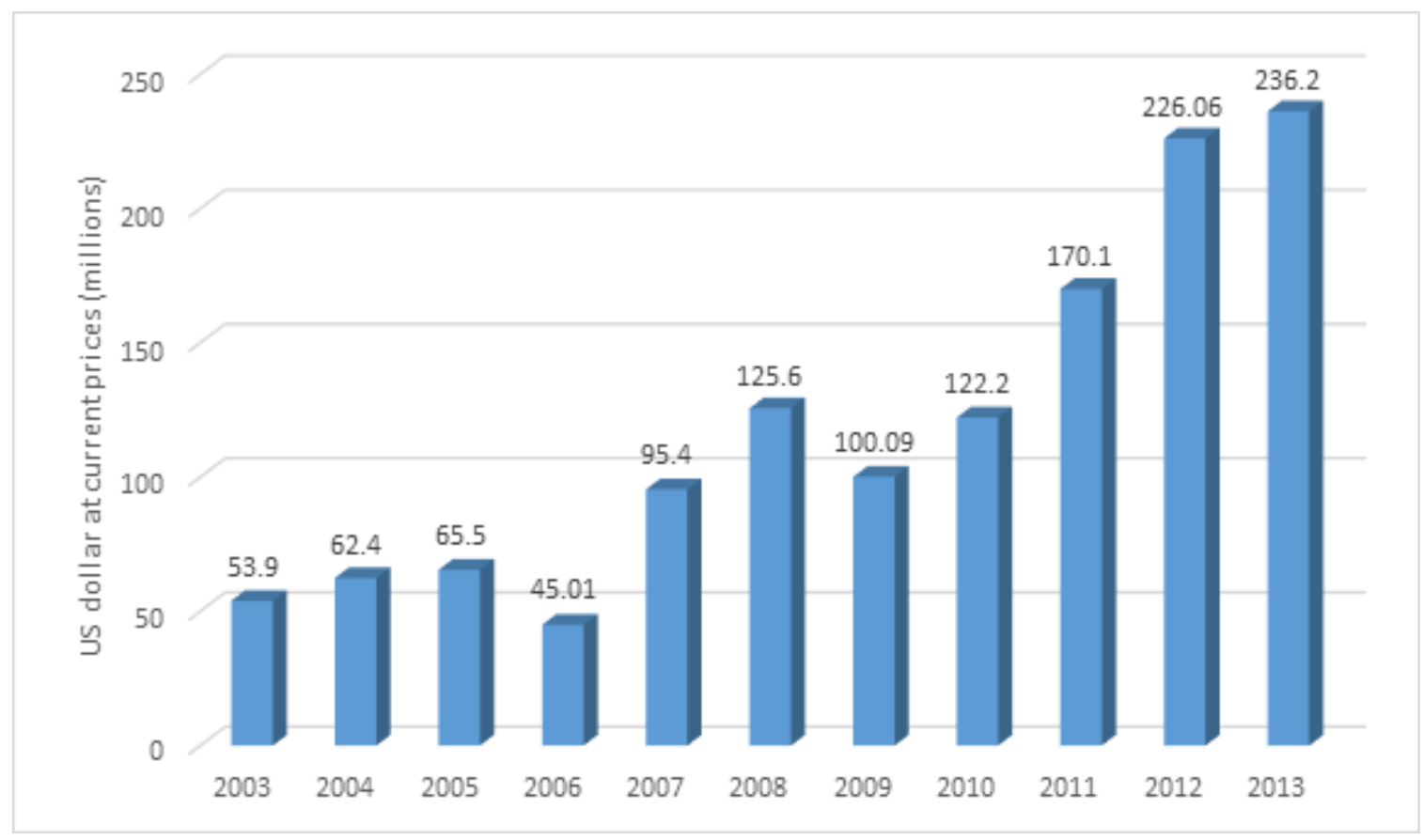

Source: WTO (2018) Statistical Program: http://stat.wto.org/StatisticalProgram/WSDBViewData.aspx?Language=E

Available data indicates that the total import value of pharmaceuticals in Ghana in 2013 was more than 236 million USD, resulting in a substantial increase on 2003 figures (Figure 1). In 2014, the value of registered pharmaceutical imports in Ghana was USD 160 million. The total value of all pharmaceutical sales represented USD 330 million (IFPMA, 2014). Based on these calculations undeclared and counterfeit medicines could represent tens of millions of USD in value.

Determining the overall scale of trade in falsified or substandard medicines in Ghana is challenging. Systematic drug testing is limited, as is public disclosure of related findings. A World Health Organization (WHO) study, using medicines collected in 2008, indicated both a high prevalence of unregistered medicines and an overall quality compliance failure rate of antimalarials of $39 \%$ (WHO, 2011). More recent research suggests a compliance failure rate of $80 \%$ for antimalarials in Ghana (Osei-Safo et al., 2014). The latter study "confirms the point that the circulation of falsified or substandard medicines could have serious public health implications", and that it "has revealed that the registration status of antimalarial medicines on the Ghanaian market has not improved since the 2011 publication of the WHO QAMSA [Quality of Anti-Malarials in Sub-Saharan Africa] report on the quality of antimalarials in selected African countries including Ghana."

The Medicines Quality Database supported by the United States Agency for International Development (USAID) contains drug analysis data for antimalarials in Ghana (United States Pharmacopeial Convention, 2015). In 2010, 446 samples of antimalarials purchased at different locations and outlets (both formal and informal) were analysed. Of the collected samples, $58 \%$ were not registered for sale in Ghana (or it was not possible to determine whether they were registered) and $29 \%$ failed quality tests. However, only $1.3 \%$

ILLICIT FINANCIAL FLOWS: ILLICIT TRADE IN COUNTERFEIT, PIRATED AND SUBSTANDARD GOODS IN GHANA @ OECD 2019 
of the total was deemed counterfeit. The latest data available, from 2011, were based on testing of only 69 samples, with $20 \%$ of the products not registered for sale in Ghana and $6 \%$ of the total failing quality control (see Figure 2.2).

\section{Figure 2.2. Analysis of Medical Supply Samples, 2010 - $2011(\%)$}

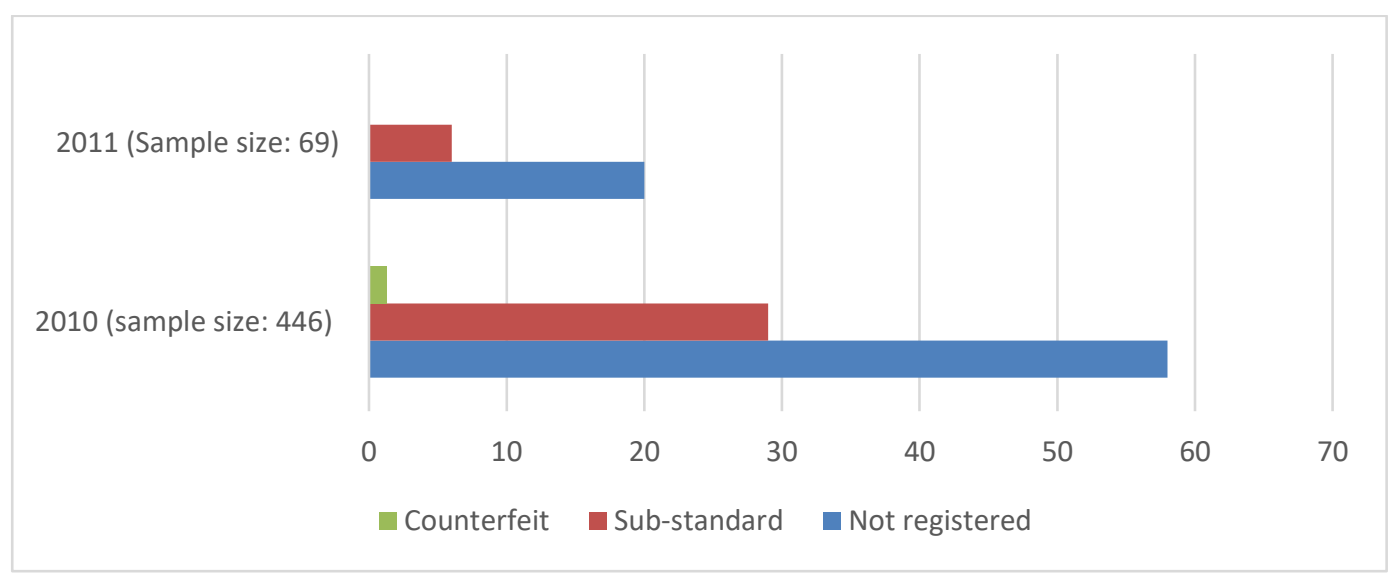

Source: OECD Secretariat, on the basis of the information provided by the Medicines Quality Database cited in the text above.

With international support, the Center for Pharmaceutical Advancement and Training (CePAT), working together with the Food and Drugs Authority (FDA) of Ghana, has also helped analyse different forms of medication in the country, including antimalarials since 2008 (GHA-INGO-Pharm-120615). None of these findings (in contrast to the aforementioned data on antimalarials) seem to have been published. According to the FDA of Ghana, however, counterfeit and substandard antimalarials appear to have declined from around $30 \%$ to $3 \%$ between 2008-14 (GHA-Gov-Drug-090615). As one possible explanation, the Global Fund to Fight AIDS, Tuberculosis and Malaria began providing low-cost antimalarial treatment, which has reduced the profit potential for people selling unregistered or counterfeit medication (GHA-Gov-Drug090615).

In research on other drugs, a 2012 study found the uterotonic drugs oxytocin and ergometrine (used in maternal health and both on the WHO's List of Essential Medicines) to be of uniformly poor quality in Ghana. ${ }^{4}$ All told, $89 \%$ of the tested samples were below British Pharmacopoeia specifications, although only $2 \%$ of the tested drugs had expired (Stanton et al., 2012).

The quality of oxytocin has been a concern, due to maternal deaths caused by substandard medicine. While inadequate storage is likely an issue, deaths may also be due to substandard or counterfeit medicines. In mid-2015, the pharmaceutical company Merck and WHO Testing began testing oxytocin. A USAID-supported study in 2013 found that only $8 \%$ of oxytocin samples in Ghana had been issued marketing authorisation. More than $40 \%$ of ergometrine also lacked authorisation. In random tests, more than $90 \%$ of samples failed the quality criterion, either due to the quantity of active ingredient or lack of sterility (Karikari-Boateng, 2012).

In addition to testing antimalarials, CePAT has also tested antibiotics since 2010 and analgesics since 2013. In the view of a CePAT representative, the problem of substandard antibiotics may be as extensive as was formerly the case with antimalarials, or even more so. In 2013, the FDA of Ghana warned the public that unregistered and substandard antibiotics and oxytocin manufactured in the People's Republic of China [hereafter China] were available in Ghana (Ghana Business News, 2013). A 2014 paper found that more than $65 \%$ of antibiotic products tested in Ghana were substandard (Bekoe et al., 2014). A University of 
Ghana study in 2013 found that only one antibiotic sample tested had a registration number from the FDA of Ghana printed on its label; $69 \%$ did not comply with the requirement for an active pharmaceutical ingredient (Egbo, 2013). A representative from a company working with technical solutions to prevent counterfeiting of medicines and other products believes the overall problem of counterfeit medication is growing (GHA-Corp-Agri-1000615).

UNODC and international law enforcement agencies point to the growing illicit use of prescription drugs classified as non-narcotic such as tramadol (an opioid pain medication) and ephedrine (a stimulant). The phenomenon is significant not only in Ghana, but in the region as a whole (GHA-Gov-LE-290515 \& 100615; VIE-UNODC-030515) and could have repercussions in terms of driving the demand for the expansion of the illicit trade in these normally legal prescription drugs. In West Africa alone, approximately 900 shipments of tramadol were intercepted between the beginning of 2012 and mid-April 2014. The largest number of seizures occurred in Benin, but seizures destined for Niger were also made in Ghana (UNODC, 2014). In addition to being used recreationally or to enhance work capacity, such prescription drugs are used by Islamist terrorists in West Africa. Tramadol has reportedly been used by Boko Haram (The Guardian, 2013; VIE-UNODC-030515), and ketamine by the Movement for Oneness and Jihad in West Africa (Thiénot, 2013).

The existence of such illicit practices seems to be common knowledge among pharmacists and their clients. In a 2015 survey for this study, a quarter of interviewed pharmacies stated their competitors sold fake medicines, just over half stated they did not know and the remaining $(23 \%)$ stated that competitors did not sell fakes (Vibrand Research, 2015). Of those claiming their competitors sold fakes, two-thirds stated that fakes are easier to obtain than genuine medication. Over three-quarters stated that profitability was higher when selling fakes. Just over half of the pharmacists also stated they had been offered counterfeit products for purchase. ${ }^{5}$

Similarly, for consumers, over half of consumers interviewed for this case study stated they had seen fake medicines for sale. This may undermine consumer confidence in the pharmaceutical sector. Another problem is that consumers are often likely to be unaware whether medicines are counterfeit. In a survey of legitimate businesses selling pharmaceuticals, over $98 \%$ of respondents believed counterfeit products were on the market. Estimates ranged from over $50 \%$ to less than $10 \%$ being fake. Informal networks, as well as registered retail outlets and pharmacies, are involved in selling fakes (Vibrand Research, 2015).

\section{Counterfeit and non-approved agrochemicals}

The agricultural sector forms an important part of the Ghanaian economy, employing $42 \%$ of the country's workforce (World Bank, 2015a) and producing significant exports - a fifth of the world total (World Cocoa Foundation, 2012). Further, Ghanaian cocoa commands a premium price due to its high quality (GHACorp-Agri-090515). Cocoa is one of the three most important export commodities for Ghana, along with gold and crude petroleum. Cocoa-related exports alone generated over USD 3 billion in export revenue in 2012, representing over 7\% of Ghana's gross domestic product (GDP) (World Bank, 2015b) and almost $19 \%$ of that year's export revenue (IFPMA, 2014). In 2013, cocoa-related exports reached USD 5.7 billion, exceeding both gold and crude petroleum exports (Figure 2.3). 
Figure 2.3. Ghana top three exports, 2013 ( USD millions)

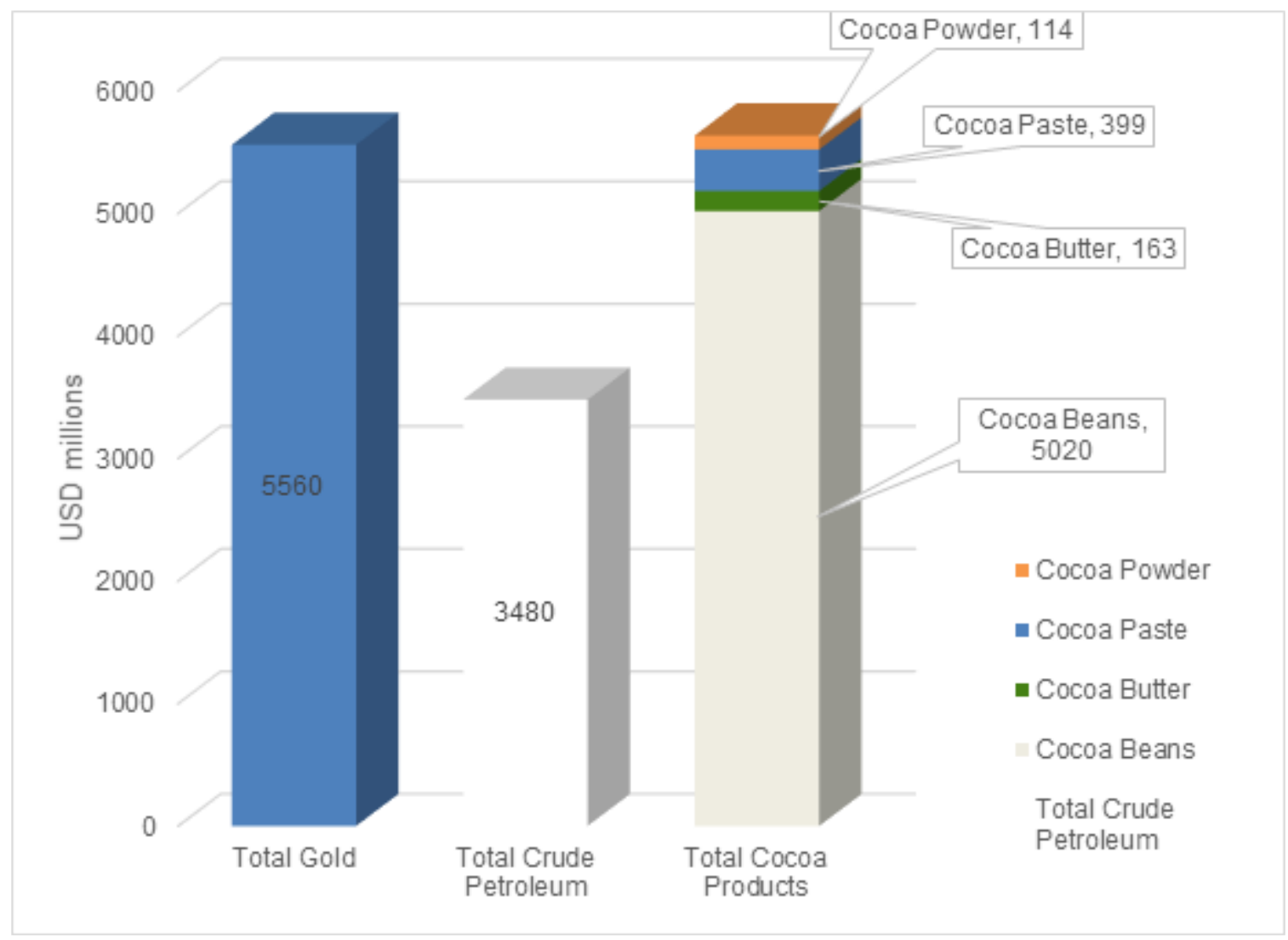

Source: OECD (2013), using Comtrade data from 2013, Country Profile (Ghana) http://atlas.media.mit.edu/en/profile/country/ghal.

The economic importance of the agricultural sector means that fertiliser and agrochemical imports are significant. In 2012, Ghana imported more than USD 310 million worth of pesticides, and over USD 250 million of fertiliser (OECD, 2013). In some cases, agrochemicals may be counterfeit, but a larger problem is the import or smuggling of unapproved and banned products that are sold to farmers. Subsidised government-procured products are also diverted to neighbouring countries. The Environmental Protection Agency, an authority under the Ministry for Food and Agriculture, must approve fertilisers and agrochemicals in Ghana.

The Cocoa Board regulates the cocoa sector, and the Cocoa Research Institute evaluates and controls products. Several years ago, it initiated CODAPEC to raise productivity and yield, whereby mass sprayings in cocoa zones are provided free of charge to farmers, although the government provides only two free sprayings per year, and farmers need to finance their remaining needs. Government-sponsored sprayings use products marked "not for sale" (GHA-Corp-Agri-120615; GHA-Corp-Agri-090515). The provision by the Ghana Cocoa Board of free fertiliser and agrochemical spraying to farmers has, however, created the preconditions for illicit outflow of "not for sale" CODAPEC products to neighbouring countries as these are often diverted and sold illegally abroad. This has two implications. First, Ghanaian cocoa farmers are subsidising "non-purchases". Among other things, the Ghana Cocoa Board buys large amounts of fertiliser and agrochemicals. An external expert estimates these purchases are worth USD 200 million annually (GHA-IO-Econ-180615). Second, farmers in other countries are using illicitly exported fertiliser and 
agrochemicals, with the organisers of this illicit trade acquiring illegal income. According to international observers, the Board's problems go beyond lack of transparency and constitute corruption. Economic rentseeking behaviour appears to impede reforms that could have the potential to enhance productivity in the Ghanaian cocoa sector (GHA-IO-Econ-180615).

In addition to the illegal trade of free subsidised goods, the use of counterfeit agrochemicals have clear economic consequences for Ghanaian farmers. Japan has previously rejected Ghanaian cocoa exports because of pesticide contaminants (GhanaWeb, 2013c). One could speculate that recurring problems with pesticide contamination or changes in import country standards could have more serious impact in the future. The European Union, for example, has banned the import of dried beans from Nigeria due to concerns over pesticide residues (Food Standards Agency, 2015; GHA-Corp-Pharma-120615). In addition to simple misapplication of approved agrochemicals, the presence of falsified and non-approved chemicals may pose risks in terms of contaminating cocoa exports, which in turn could create health concerns for those markets importing Ghanaian cocoa and cocoa products, resulting in considerable economic threats to one of Ghana's primary revenue sources, given it is a leading export commodity. Contaminants of other agricultural products have a lesser economic consequence, although local consumer health and farmer livelihoods will still be impacted.

Illicit trade affects all types of agrochemical pesticides, fungicides, insecticides and herbicides. The presence of products unapproved by Ghanaian authorities is of great concern. Estimates of the scale of the problem are mixed, however. The agrochemical supplier CropLife Ghana estimates that the problem with counterfeit agrochemicals has reduced in recent years, although the frequency of unauthorised products has increased (GHA-Corp-Agri-090515). A Ghanaian representative of the World Cocoa Federation has estimated that $40-50 \%$ of agrochemicals used for cocoa cultivation in Ghana might be unapproved (GHA-Corp-Agri-120615). The Environmental Protection Agency of Ghana (EPA), however, believes the problem of unapproved agrochemicals has declined and is significantly smaller (GHA-CorpPharma-120615), although this view does not seem to be shared by those in the industry. In a limited survey of businesses selling agrochemicals to farmers, over $60 \%$ stated that sellers had approached them with counterfeit products (Figure 2.4). In addition, $60 \%$ believed the government had little effect on stopping counterfeits, and $73 \%$ stated the government should be doing more in this regard (Vibrand Research, 2015). 
Figure 2.4. Responses of 70 businesses selling agrochemicals ( in \%), 2015

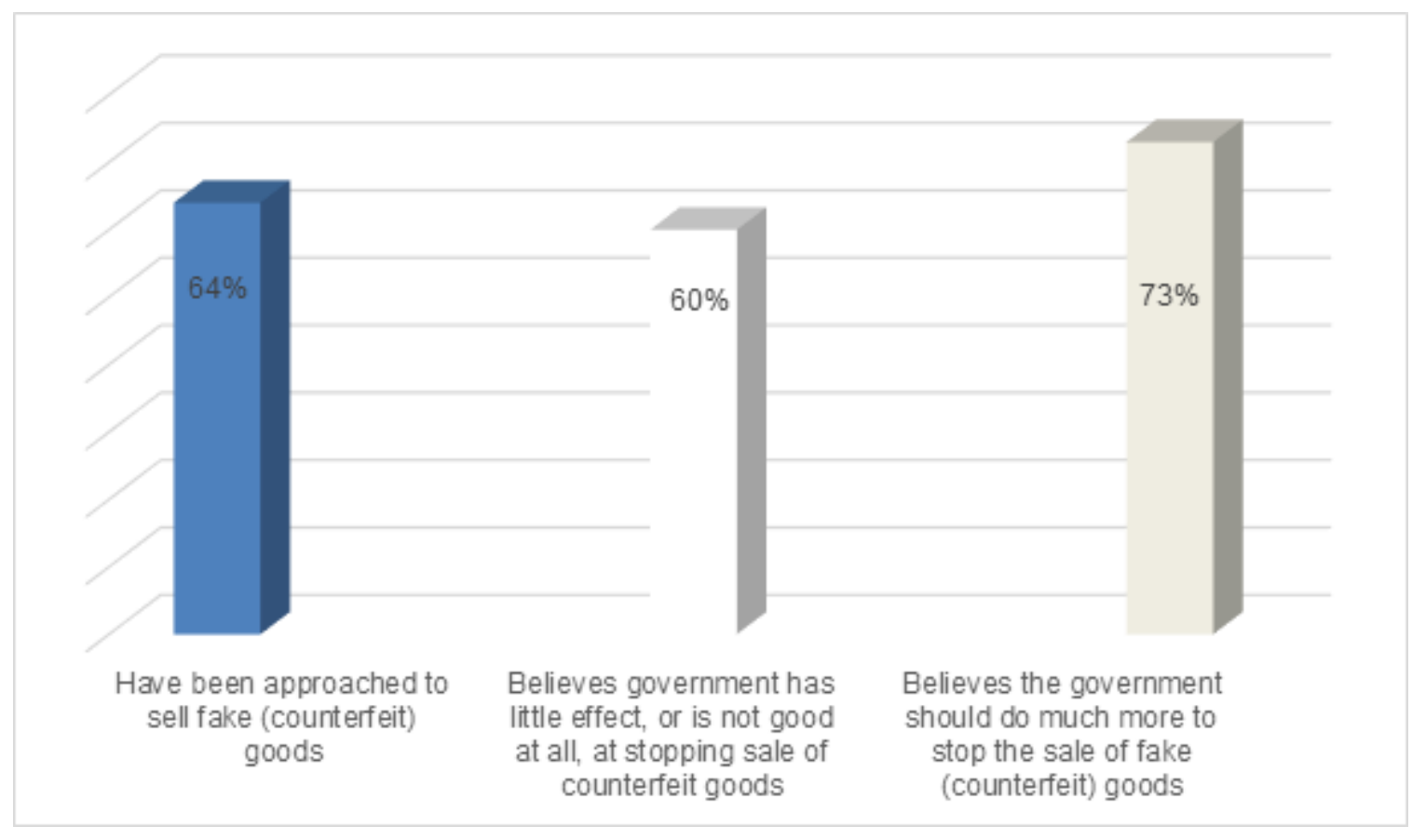

Source: Vibrand Research (2015), Counterfeit Study Ghana.

\section{Counterfeit, pirated and substandard consumer goods}

Generally perceived as lesser crime, or even normal, the trade in counterfeit, pirated and substandard consumer goods is nonetheless illegal. At scale, it generates significant revenues, while depriving the state of tax revenues. It also deprives legitimate enterprises of income, due to unfair competition.

Although there are few assessments regarding the overall scale of the illicit trade in counterfeit, pirated and substandard consumer goods in Ghana, consumers, commercial actors and government representatives all agree that this trade is widespread across Ghana and West Africa, and affects a wide range of product categories including baby foods, biscuits, canned foods, textiles, electrical goods, electrical cables, medicines, mobile telephones, vehicle components, fast moving consumer goods, fuels, printer cartridges, agrochemicals, tobacco intended for sale in other countries, alcohol, lubricants, industrial tape, clothing and cosmetics. According to one official of the Ghana Standards Authority, the leading places of origin of counterfeit, pirated and substandard goods are China, India, Turkey and Nigeria (GHA-Gov090615). The position of China and India as the top countries producing counterfeit drugs is supported by evidence from World Customs Organization seizures (WCO, 2013). Consumer perceptions, business surveys, and government reporting make clear that this trade is ubiquitous. The entire procurement chain, from public procurement down to distribution and retail, is involved. (GHA-Gov-090615).

A 2008 study financed by the European Commission provides some insights into the magnitude of the trade, based on feedback from consumers and businesses in Ghana. Although this study did not attempt to quantify the scale of the problem (Dunphy, 2008), it recorded, for example, that $60 \%$ of respondents (consumers) leaving an electronics market affirmed that they had knowingly purchased counterfeit and pirated electronics. Similarly $61 \%$ of respondents (consumers) leaving a textiles market acknowledged that they had knowingly purchased counterfeit textiles at least once. Over half of consumers leaving a market 
for fast-moving consumer goods admitted to having bought counterfeit, and a vast majority of consumers admitted to having purchased pirated copyrighted material (music, films, software). Moreover, in a consumer survey commissioned for this study (Vibrand Research, 2015), over two-thirds of respondents stated that consumers find it either completely or somewhat acceptable to buy fake products. Almost half stated they themselves had bought fake products within the last 12 months. Consumers identified electronic goods and fashion items as the counterfeit and pirated products they were most likely to buy. Food and medicines were also among the top four categories of fake products that a majority of respondents had themselves seen for sale.

In a small-scale survey of different businesses selling consumer goods, primarily in the Accra area (Vibrand Research, 2015), the median perception response was that fake goods constituted $20-30 \%$ of the total market. Over two-thirds of respondents believed their competitors were selling counterfeits. And over $80 \%$ stated that sellers of counterfeit and pirated products had approached them. Surprisingly, $13 \%$ of businesses even admitted to selling counterfeit and pirated goods themselves, suggesting the real figure is significantly higher as businesses are unlikely to admit to illegal activity.

\section{Box 2.1. Other illicit activities related to trade in normally legal goods}

In the course of this research, it became apparent that evading customs duties through undervaluation, false categorisation and corruption of customs officials constitutes a significant problem that deprives the Ghanaian state of huge amounts of income.

Fuel subsidies are another problem that creates economic incentives for illicit flows out of Ghana, primarily to Togo, a neighbouring country where fuel prices are higher. Oil stolen in Nigeria is also imported into Ghana via Europe, where the oil is refined (GHA-Gov-LE-100615; GHA-Gov-LE-290515 \& 100615). The import and sale of substandard fuels are also a problem. Poor quality petrol, with lower octane levels, is imported and sold even in large petrol station chains (GHA-Gov-090615). There is also a problem of substandard diesel fuels, where sulphur levels are too high (NIG-Corp-Auto-120615). In both cases, the life span of engines is reduced.

Tobacco is smuggled into Ghana without payment of taxes. However, industry sources suggest this represents only $3.5 \%$ of total consumption, or about 80 million cigarettes per year. In other West African states, the problem is far more extensive (e.g. $34.5 \%$ in Guinea-Bissau, $22.7 \%$ in Mali, and $10.9 \%$ in Côte d'Ivoire) (NGA-Corp-Trade-030715). The smuggling of alcohol to avoid excise duty has also been a problem in Ghana, and other West African states (Ghana News Agency, 2010). 


\section{Networks and actors of illicit trade}

The illicit trade in goods displacing normally legal goods covers a broad range of criminal activities. But some particular characteristics are worth summarising before detailing the key enablers of these crimes. A broader structure over and above the retailers who sell products to consumers exists in both the formal and informal sectors.

The informal sector employs a majority of Ghana's workforce. ${ }^{6}$ This implies an enormous scale of unregulated (or under-regulated) channels with the potential of providing counterfeit, pirated and substandard goods. Consequently, street sellers provide an important channel for illicit trade. Although selling counterfeits may be criminal, they are an inevitable consequence of the large and unregulated informal sector. The regulatory authorities are primarily focused on ensuring the compliance of registered and official entities. Therefore, the problem of counterfeit, pirated and non-compliant products in the informal sector remains relatively unaddressed.

The higher level perpetrators of illicit trade are "businessmen" operating legitimately registered enterprises. They orchestrate movements of illicit articles through shipments containing undeclared or falsely declared goods, or by cross-border smuggling. Corrupt officials and Ghana's porous borders are key enablers of these flows. Furthermore, high-level beneficiaries of illicit trades enjoy a certain degree of protection from public officials in Ghana. A patronage system dispenses monies to political parties, religious institutions or tribal elites. This is in addition to direct corruption of key officials. Some elected officials, or their relatives, may own businesses profiteering from illicit trade. Cases have been identified in the fishing sector and petrol stations in border regions where smuggling is common (GhanaWeb, 2013b; GHA-Gov-110615; GHA-Gov-LE-110615; GHA-Gov-LE-120615). In addition to "businessmen", state officials profit from corruption in public procurement. This contributes to illicit goods flowing into the country. It also contributes to the flow of procured subsidised goods out of the country to neighbouring states (GhanaWeb 2013b; GHA-Gov-110615). ${ }^{7}$

A key enabling component is the availability of counterfeit, pirated, substandard, non-approved goods on the global market. Such goods originate primarily in Asia, particularly China (OECD, 2016), and their availability is due to several factors including the extensive legitimate trade between Ghana and China, Ghana's lack of domestic enforcement capacity, China's low levels of effective control over its exports and the lack of international frameworks to address the global dimensions of these illicit flows. Ghana, as well as other West African and developing countries in general, are severely limited in their ability to address such flows.

\section{Corruption networks}

Several respondents claim corruption has increased in recent years in Ghana, creating an environment conducive for illicit trade. ${ }^{8}$ The entire trading sector is widely perceived as vulnerable to corruption. Highlevel sources within law enforcement agencies believed that official data relating to counterfeit, pirated and substandard goods are not reliable due to high levels of corruption in the relevant authorities. Law enforcement agencies and the private sector have pointed to corruption as the critical constraint on 
regulatory systems across the supply chain, including customs, and within the judiciary (GHA-Corp-Agri1000615; GHA-Gov-090615; GHA-Gov-110615; GHA-Gov-LE-100615; GHA-Gov-LE-110615; GHA-GovLE-120615; GHA-Gov-LE-290515 \& 100615). ${ }^{9}$

Sources for this study further suggested there is cultural acceptance of counterfeit trade, which is often not perceived as a criminal activity. The leading people involved are primarily seen as traders (GHA-Gov090615; GHA-Gov-LE-290515 \& 100615), and often donate to political parties, religious institutions or to chiefs. ${ }^{10}$ This results in illicit financial flows indirectly financing the Ghanaian political, religious and tribal elite (GHA-Gov-110615; GHA-Gov-LE-100615; GHA-Gov-LE-110615; GHA-Gov-LE-290515). The wide support enjoyed by such "big men" means they can influence law enforcement and the judiciary, effectively becoming untouchable or protecting certain individuals (GHA-Gov-LE-110615). Sources suggested that in cases where charges are brought, criminal proceedings are often not fully pursued due to the payment of bribes or pressure to adjourn or drop cases (GHA-Gov-LE-290515 \& 100615).

Ghana Police Service sources believe smaller actors involved in the illicit trade of counterfeit goods do not necessarily rely on powerful people to protect them from prosecution. These smaller players can make protection payments directly to officials, and do so through bank transfers and cash payments. The latter appears more frequent, and makes payments harder to track, measure and counter (GHA-Gov-LE120615; GHA-Gov-LE-110615). International law enforcement agencies claim it is virtually impossible to ensure that politically "protected" individuals are prosecuted in Ghana (GHA-Gov-LE-290515; GHA-GovLE-100615).

\section{Box 3.1. An example of the severe damage that corruption can cause}

A fire in Ghana's Central Medical Stores in January 2015 illustrates the extreme steps that may have been taken to cover up corruption (Laary, 2015a). Multiple sources interviewed stated that the fire was preceded by an investigation into improper activities. An onsite inspection of medical stocks had been planned. The fire destroyed more than 230 million GHS (USD 55 million) worth of uninsured medical supplies. Almost three years after the incident, in November 2017, the Health Minister of Ghana announced that investigations were complete. The report has been submitted to the Auditor-General for a forensic audit to be conducted into the findings.

As of mid-2018, no one had yet been prosecuted nor held liable for the incident. However, representatives of law enforcement agencies and international NGOs suspected that this was an arson set to destroy evidence of corruption and mismanagement.

Customs was also identified as a particularly weak link (GHA-Gov-LE-120615; GHA-Gov-LE-100615; GHA-Gov-110615), suggesting that corrupt customs officials from the Ghana Revenue Service are in effect economic beneficiaries of the extensive illicit trade in counterfeit, pirated and substandard goods. Law enforcement officials among others also pointed out the collusion of FDA officials signalling that these officials receive bribes to approve suppliers of substandard medication or to turn a blind eye to improper activities. With regard to agrochemicals, corruption may be affecting the effectiveness of the Environmental Protection Agency (EPA). EPA representatives said it is difficult to know whether inspectors are corrupt, although there had been no cases discovered as yet (GHA-Corp-Pharma-120615). Higher level corruption is likely involved in the procurement processes of the Cocoa Board and the diversion of "not for sale" fertiliser and agrochemicals. As stated previously, these are intended for Ghanaian farmers as part of the government support programme, but are often diverted to neighbouring countries.

If it were a public enterprise, the Ghana's Cocoa Board would be the biggest company in the country, with an annual turnover of around 2.5 billion USD (GHA-IO-Econ-180615). The Cocoa Board regulates Ghana's 
cocoa sector and sets the purchase price for all cocoa produced by Ghanaian farmers. It undertakes largescale procurement of fertilisers and agrochemicals, which are then provided free of charge to cocoa farmers. Furthermore, it controls the quality of Ghanaian cocoa exports (GHA-Corp-Agri-090515).

Cocoa sector experts who participated in this study pointed to the lack of transparency within the Cocoa Board, which could be a potential driver of corruption. The acquisition of fertilisers and agrochemicals in subsidy programmes is not considered competitive. ${ }^{11}$ One cocoa expert claimed the procurement list includes companies that have never imported fertilisers. The expert described the Cocoa Board as "engaged in 'rent-seeking' behaviour" (GHA-IO-Econ-180615).

Poor public sector procurement oversight, as well as challenges regarding the enforcement of standards and customs clearance, is further illustrated by the "condom case". A public contract for the Ghanaian Ministry of Health procured 130 million condoms valued at over USD 4 million. Yet, it resulted in the delivery of counterfeit and substandard condoms (GhanaWeb, 2013d). An investigative committee found that the lack of implementation of the policy and institutional review of the procurement and supply chain system has contributed to several loopholes. The lack of adherence to both the letter and the spirit of the Public Procurement Act resulted in a situation where a presumed international competitive tender essentially ended up being a sole-sourced tender. (GhanaWeb, 2013a)

The committee also added the FDA appears to impose a weak regulatory regime on the public sector, leading to cases where unregistered products are procured and imported. ${ }^{12}$ The committee also found serious anomalies and inconsistencies in the clearance of goods at ports of entry, as well as with the receipt, storage and distribution of goods by the Central Medical Stores (Guilford, 2013). Relevant legislation, the 2003 Public Procurement Act (Public Procurement Authority, 2003) and institutions (Ghana Public Procurement Authority) were all in place at the time. The "condom case", however, illustrates that even if an appropriate framework exists, it does not guarantee that rules and procedures will be followed.

\section{Weak law enforcement}

Enforcement of the law is seen by most public and private sector representatives as the primary problem in Ghana, rather than the legislative framework itself. The key regulatory authorities responsible for enforcement in areas of primary focus for this paper (i.e. medicines, agrochemicals and consumer goods) are, respectively, the Ghana Food and Drugs Authority (FDA), the Environmental Protection Agency (EPA) and the Ghana Standards Authority (GSA).

An FDA representative has estimated that $20-30 \%$ of medicines in Ghana are purchased in the informal sector, despite this being illegal (GHA-Gov-Drug-090615). This suggests that efforts to clamp down on such sales have had limited effect. In a survey of pharmacies for this study, only a quarter said they were subject to annual or more frequent controls of whether they were selling counterfeit products (Vibrand Research, 2015). This survey focused predominately on Accra. Control frequency may be even lower in more remote parts of the country (where the problem of counterfeit and substandard drugs is also believed to be greater). Most pharmacies stated they believed the government was good at stopping the sale of counterfeit products, although over three-quarters of respondents said it needs to do much more.

Robust legislation on drug sales empowers the state to impose prison sentences between 15 and 25 years for anyone violating the Public Health Act (Parliament of Ghana, 2012), but since its implementation in 2012, the legislation has resulted in only one criminal conviction. Moreover, in that case, the final sentence was below the mandatory minimum (GHA-Gov-Drug-090615).

The Plants and Fertiliser Act (2010) established the Plant Protection and Regulatory Services Directorate of the Ministry of Food and Agriculture, under which the EPA serves, as the national institution for plant 
protection (Ghanaian Ministry of Food and Agriculture, n.d.). The importation of fertilisers and agrochemicals is regulated, and all importers are subject to approval.

The EPA has approximately 80 employees dealing with unapproved trades. Although they are supposed to ensure that only approved fertilisers and agrochemicals are available to farmers, many also fulfil other functions. $40 \%$ of Ghana's entire workforce is found in the agriculture sector, and yet the ability of the authorities to carry out regulatory controls is highly limited, as reflected in the following respondent comments:

- Crop Life, the association of agrochemical importers and distributors in Ghana, stated that the last large-scale control swoops conducted by the EPA occurred in 2008 and 2010. If effective EPA inspections were in place, it would likely reduce the availability of unregistered products (GHACorp-Agri-120615; GHA-Corp-Agri-090515).

- Awareness-raising initiatives, such as radio programmes informing farmers about the law, have been discontinued due to limited resources (GHA-Corp-Agri-120615).

- The training and testing of vendors to become certified resellers of agrochemicals was also discontinued in 2012 due to lack of funding. The law, however, requires certificates of training for selling agrochemicals. The EPA also lacks resources to oversee whether sellers actually hold certificates (GHA-Corp-Agri-120615).

- The EPA states it lacks the capacity to verify that all imported products are compliant. Efforts have been made to establish a quality control laboratory, but this is expensive and sufficient funding is not yet in place (GHA-Corp-Pharma-120615).

Given the lack of controls, unapproved agrochemicals and counterfeit products with mimicked labels are sold openly. At the Kejetia market in Kumasi, a leading hub of the trade in illicit agrochemicals, sellers of unauthorised products advertise overtly with loudspeakers (GHA-Corp-Agri-120615; GHA-Corp-Agri090515).

Enforcement of legislation related to counterfeit goods is no better than that of illicit trade in medicines and agrochemicals. Since illicit trade in counterfeit goods is a low priority and authorities lack capacity, there are few deterrents. Additionally, for areas not covered by the Public Health Act, legal consequences are much lower. Trade mark infringement related to counterfeit and pirated electronics, for example, is merely a misdemeanour, ignoring potential safety hazards posed by non-compliant products (GHA-Gov-LE120615).

Most public and private sector representatives view the implementation, or enforcement, of the legal framework as the primary problem, rather than the framework itself. In other West African states, however, the legal frameworks themselves may suffer from more significant shortcomings. These could include the inability to protect intellectual property rights and to empower the state to act against illicit trade.

According to official Ghanaian statistics, 169 counterfeiting offences were reported in 2014. This represents only $0.08 \%$ of total reported offences. Given the seemingly massive scale of the problem, this is an extremely low figure. The number of reported counterfeiting offences has remained relatively stable since 2011 (GHA-Gov-110615).

The Ghanaian police force has an Intellectual Property Offences Section (POS), which is part of the fraud unit. It is led by a senior officer and comprises ten additional officers. The POS deals with major cases in Accra. In other regions, the general police deals with IPR infringement cases. The police do not check whether goods being sold are counterfeit, pirated or infringing intellectual property but rather tend to react to reports from rights holders. Resources for dealing with counterfeit and pirated goods are limited, since there is pressure to focus on crimes of greater political concern (GHA-Gov-LE-120615). Spot checks and retail control are also largely ineffective. For example, the FDA does not focus its activities on the informal 
markets where most Ghanaians actually buy their food (GHA-Gov-Justice-100615), while institutions such as the Ghana Standards Authority (GSA) focus primarily on ensuring that legitimately registered enterprises comply with legislation.

The large volume of imports, combined with limited resources and the possibility of corruption, makes it difficult to conduct domestic testing to ensure quality and compliance of imports. To address this problem, leading figures at the GSA have proposed pretesting imported products abroad. This would ensure quality standards before products reach Ghana (GHA-Gov-090615). To make this a reality, the Ghana Conformity Assessment Programme developed a programme with the General Society of Surveillance (SGS), a worldwide company providing inspection, verification, testing and certification services. The agreement, signed in August 2014, has been delayed (GHA-Gov-090615), partly due to the high cost of testing out of the country.

\section{Border controls}

As with medicines and agrochemicals, importing counterfeit, pirated and substandard goods of any type into Ghana is relatively easy due to three factors: the porous nature of Ghana's borders; trade facilitation between ECOWAS members; and high levels of corruption within the Customs Service and Border Control.

Counterfeit or unregistered medication mostly cross into the country as goods in regular shipments, although the drugs are either not declared or falsely declared. Since authorities physically control only a small proportion of shipments, the likelihood of detection is low (VIE-UNODC-030515). According to several inside observers, extensive corruption within the customs service exacerbates the challenge of effectively controlling the illegal import of counterfeit and falsified goods through shipments (GHA-CorpAgri-1000615; GHA-Gov-110615; GHA-Gov-Drug-090615; GHA-Gov-LE-110615; GHA-Gov-LE-120615; GHA-Gov-LE-290515 \& 100615; GHA-Gov-Pharm-100615; VIE-UNODC-030515). A government assessment leaked to the media revealed the extent of broader corruption within the Ghana Revenue Authority (under which customs lies). Fraudulent activities by importers are estimated to generate estimated annual revenue losses of GHS 36 billion (USD 8.7 billion) for the state (GHA-Gov-LE-100615).

The Criminal Investigations Department of the Ghana Police Service also signalled that Ghana's weak land border controls are enabling importers to bring counterfeit goods into neighbouring countries and then via land borders into Ghana. For example, products are brought into the free port of Lomé in Togo before being smuggled into Ghana. Nigerians also import illicit goods directly to Nigeria and then transport them by land routes to Ghana (GHA-Gov-LE-120615). The lack of effective border control in Ghana has facilitated the entry of banned and non-registered products, as well as the large-scale diversion of subsidised fertiliser out of the country (GHA-Corp-Pharma-120615). Authorities also have limited capacity for controlling whether goods in transit to other countries (for example, destined to Ghana's landlocked neighbours) are being diverted and remaining in Ghana.

According to the International Chamber of Commerce in Ghana, efforts to restrict all textile imports to one single port, in order to facilitate inspections, initially helped reduce illicit textile inflows. But the illicit flows resumed as textile traders adapted by beginning to import textiles into neighbouring countries only to smuggle them into Ghana across land borders (GHA-Corp-Finance-200915).

\section{Illicit trade at the local and international level}

Most law enforcement officials interviewed for this study believe that Ghanaian businessmen are the primary drivers of the illicit trade in counterfeit, pirated and substandard goods. They also believe that both 
legitimate retailers and informal vendors sell counterfeit and pirated products and that banks and financial institutions are used for illicit transactions. A representative from the Presidential Special Operations Taskforce and others described traders in Ghana as a group highly prone to fraudulent behaviour (GHAGov-LE-100615). According to the Criminal Investigations Department of the Ghana Police Service, the perpetrators of counterfeiting cases often operate properly registered companies (GHA-Gov-LE-120615; GHA-Gov-110615). Certain anti-malarials manufactured in Ghana have also been found to be substandard (United States Pharmacopeial Convention, 2015) and counterfeits are also produced in the country. They are packaged in false or re-used genuine packaging, as are substandard products (VIE-UNODC-030515).

Although Ghanaians are key drivers of the trade, these goods largely originate outside of the country. China is Ghana's largest trade partner, with the value of imports from China reportedly exceeding USD 4 billion (Laary, 2015b), whilst the country has been identified as the main source of counterfeit, pirated and substandard goods in Ghana. Not only are Chinese businessmen active in West Africa, but African traders have a significant presence in China, particularly in Guangzhou (PM News, 2013).

India is the other major source of imported medicines in Ghana. According to a leading professor of law and population health, public health experts have expressed scepticism over the quality of Indian export quality controls (CAD-Analyst-220615), though India has put in place policies to address the issue of counterfeits (see Box 3.2).

\section{Box 3.2. Addressing counterfeits in India}

The Government of India recognises that substandard drugs are of concern, and has taken a number of actions to address this problem. For example, it provided assistance for strengthening the State Drug Control Departments during the present five-year plan (2012-17). A whistle-blower scheme encouraged public participation in the detection of spurious drug movements in the country, and the 2008 Drugs \& Cosmetics (Amendment) Act made penal provisions more stringent. This amendment enabled the establishment of special designated courts to hear offences related to spurious and adulterated drugs (Indian Press Information Bureau, 2013).

Most counterfeit and substandard agrochemicals are also thought to originate from Asia, particularly China (GHA-Corp-Agri-120615) ${ }^{13}$. In some cases, manufacturers of such goods are legitimate producers selling products not approved for use in Ghana. In others, however, manufacturers produce fake products that infringe on the trademarks of genuine products (GHA-Corp-Agri-120615; GHA-Corp-Agri-090515).

In addition to Ghanaians importing Chinese manufactured goods, Chinese individuals active inside Ghana also supply goods to Ghanaian traders. The FIC has identified cases of Chinese commercial actors cooperating with local partners to avoid the GHS 500000 (USD 120 000) investment required of foreign companies. Ghanaians are only required to invest GHS 50000 (USD 12 000). The FIC has also detected Chinese actors using Ghanaians to transfer money on their behalf. As Ghanaian citizenship can be obtained by marriage, it also seems Chinese have married Ghanaians to facilitate business activities inside Ghana (GHA-Gov-110615).

Ghana has only a few bilateral agreements regarding the forfeiture of assets, but none with China - its biggest source of counterfeit, pirated and substandard goods. This leaves Ghana without any legal means of recovering the proceeds of crime at their origin (GHA-Gov-090615). To deal with counterfeits, China has put in place a plan of action since 2015, which has the potential to mitigate the problem of counterfeits departing from China towards not only Africa, but also the rest of the world (see Box 3.3). 


\section{Box 3.3. The Chinese "Fair Wind Action" to deal with counterfeits}

In April 2015, the General Office of China's State Council circulated the 2015 Key Tasks on Cracking Down on Infringement and Counterfeiting. For the first time, it put forward the "Qing Feng Action" (or "Fair Wind Action" translated into English) as demonstrated in Task No.8. This is a three-year plan to safeguard the integrity of "Made in China" products in the world, including in Africa. A main focus is to establish sound mechanisms for law enforcement coordination across countries. At the time of this study, it was too early to judge what practical impact this strategy might have for Ghana or West Africa (State Council of the People's Republic of China, 2015).

Public representatives interviewed for this case study emphasised the involvement of Nigerian traders in the counterfeit trade (GHA-Gov-110615; GHA-Gov-Drug-090615; GHA-Gov-Justice-100615; GHA-GovLE-120615), which also involves the import of counterfeit medication via Nigeria, and Nigerian narcotics money and fraud scams associated with the illicit trade in medicines to launder money and generate further profits (NGA-Analyst-250615).

\section{Box 3.4. The Illicit Tobacco Trade: Routes and Foreign Actors}

Almost all illicit cigarettes in Ghana have been smuggled from abroad. A major source of tobacco is the Jebel Ali Free Trade Zone in the United Arab Emirates. In some cases, falsely declared cigarette shipments are smuggled into Ghana directly. However, the Lomé Port in Togo is the most common route. Cigarettes are brought to Lomé and declared as being in transit to another country (such as Burkina Faso, Niger or Côte d'Ivoire). They are then taken to northern Togo or Burkina Faso and are finally brought into Ghana. The Lomé Port is also a major entry point for cigarettes destined for Côte d'Ivoire, as well as Mali. Guinea, which has a flat tax on tobacco, imports far more cigarettes than needed for its domestic consumption.

This also feeds illicit flows in the region (mainly to Côte d'Ivoire and the Maghreb). Lebanese actors, long active in West Africa, play a prominent role in the region's illicit tobacco trade. Chinese brand cigarettes have also been smuggled into Ghana, although the volume has been limited (NGA-CorpTrade-030715). 


\section{IFF implications and developmental impact of illicit trade in counterfeit, pirated and substandard goods}

The illicit trade in counterfeit, pirated and substandard goods can give rise to many different kinds of risks from: lack of compliance with safety standards; to substandard foodstuffs, which can pose direct threats to consumer health; electrical components becoming fire hazards, faulty vehicle components compromising road safety, and cosmetics exposing users to unsafe chemicals. Considering the scale and variety of illicit trade in substandard products, the impact on public safety and health is likely significant.

\section{The challenge of measurement}

Illicit activities related to counterfeit, pirated and substandard goods are covert by nature which makes it difficult to measure their scale and impact, both within Ghana and globally. There have been no systematic efforts to gather data on the prevalence of such counterfeit, pirated and substandard goods, except for certain types of medication, although the limited data that exists - including media reports of high-profile incidents, surveys of consumers and insights of stakeholders - does offer insights into the magnitude and its detrimental impacts.

There is some effort to collect data for pharmaceuticals - certain types of illicitly traded medication have been assessed, but to a limited extent considering the variety of medications and scale of the problem. This is not the case for counterfeit, pirated and substandard agrochemicals and consumer goods, where real statistical evidence simply does not exist.

As a senior civil servant expressed it, "it is hard to prescribe effective treatment without being able to effectively diagnose the problem" (GHA-Gov-Pharm-100615). The FDA of Ghana has also not measured the compliance of medicines used in public hospitals (GHA-Gov-Drug-090615), and several respondents have suggests that FDA employees may be corrupt, which in turn has an impact of public awareness about non-compliance (GHA-Gov-Justice-100615; GHA-IO-Econ-180615; GHA-Gov-LE-120615).

Several interlocutors cited a lack of co-operation, coordination and information sharing between government agencies, and suggested the health sector is perceived to be poorly organised, making limited systematic efforts to track the medical histories of patients (GHA-Corp-Agri-1000615; GHA-Gov-Pharm100615).

The private sector is also reluctant to make data relating to illicit medicines public. In a highly politicised media environment, it was suggested that releasing such data might be interpreted as sending antigovernment signals (GHA-Corp-Agri-1000615). 


\section{Threats to public health}

The illicit trade in pharmaceutical drugs poses a grave danger to public health in a number of ways. Treatment failure is a major risk, but the trade also contributes to drug resistance, lowers public confidence in the health system and supports the abuse of addictive substances.

Substandard and spurious/falsely-labelled/falsified/counterfeit (SFFC) medicines pose direct human and physical threats to end-users. Such medicines can contain the wrong active ingredients, or no active ingredients. Thus, users often receive inadequate dosages, resulting in ineffective treatment. In the worst case, this can even cause death (GHA-Gov-Pharm-100615).

The prevalence of illicit and substandard drugs is not known. There are also no data on the health complications caused by their use or the number of lives lost (GHA-Gov-Pharm-100615). Again, Malaria, deaths related to HIV/AIDS and Tuberculosis are estimated to exceed 30000 per year in Ghana, which could imply that high levels of non-compliant medication are producing significant numbers of needless deaths. Moreover, substandard and illegally sourced medicines are used for many other conditions.

WHO, the US Department of Health and Human Services, and in-country experts interviewed for this case study recognise the risk that SFFC medicines may contribute to treatment failure, leading to increased drug resistance, or even death (WHO, 2012). Other factors such as wrongly administering drugs or environmental contamination may also contribute to this problem; nevertheless, the emergence of more drug-resistant strains of pathogens is a matter of global as well as local concern. Pathogens that enjoy a survival advantage are likely to spread.

Substandard medication also undermines confidence in public health systems. Considering the prevalence of Malaria and other diseases in the region, as well as the recent Ebola outbreak, low confidence in public health systems can have dire consequences. If health authorities are not trusted, people are less likely to seek help or comply with medical orders. This impact is exacerbated in the West Africa region by the weak capacity of health authorities. The lack of public confidence in a health system also leads to policy dilemmas regarding data disclosure about counterfeit or substandard medicines, providing an excuse not to disclose the extent of the problem, as this would further erode public confidence in medications and the health system.

International law enforcement officers based in Ghana and from UNODC are concerned about the importation and sale without prescription of drugs classified as non-narcotic but with abuse potential, such as tramadol and ephedrine (GHA-Gov-LE-290515 \& 100615; VIE-UNODC-030515). Recreational use of such drugs is already common in Ghana, as well as in the West African region. UNODC fears this abuse will become more widespread and pose a serious regional challenge due to their relative affordability and availability (VIE-UNODC-030515). Again, hundreds of shipments of tramadol alone are intercepted every year in West Africa. The vast scale of the trade raises the spectre of mass abuse. The history of massive Mandrax abuse in South Africa, with an associated violence, provides a worrying precedent. ${ }^{14}$

The use of unapproved agrochemicals also poses health risks for Ghanaian farmers and people living near farming areas due to the potential contamination of local soil and water supplies. Consumers of Ghanaian agricultural produce also risk exposure to unacceptable levels of unapproved agricultural chemicals. However, the environmental impact of such agrochemicals in Ghana has not been studied systemically or on a large scale. Indeed, quantifying the health problem is not yet possible (GHA-Corp-Agri-090515). 


\section{Negative economic impact}

The illicit trade in counterfeit, pirated and substandard goods creates a number of economic distortions, of which two particularly prominent concerns are unfair competition and revenue losses.

Counterfeit goods impact a number of domestic Ghanaian industries, including textiles, electrical cables and processed foods. Cheap Asian imports, predominantly from China, have particularly hurt the West African textile industry. In Ghana, importers of foreign textiles have under-declared import quantities, under-invoiced import values and misrepresented product categories to reduce import duties. Furthermore, imported products often carry pirate patented or registered designs, imitate designs, infringe trademarks, use falsified Ghana Standards Board marks or do not declare the country of origin (Bruce-Amartey Jr., Amissah and Safo-Ankama, 2014). Although these illicit activities are not the only factor contributing to the sharp decline in Ghana's textile industry, they are certainly contributing factors that artificially enhance the competitiveness of imported products to degrees beyond what would be possible if the laws were respected.

Illicit imports also affect competition between goods legitimately imported to Ghana. From the perspective of the Ghanaian government, falsified goods pose a problem as import duties are sometimes avoided, reducing government revenues. From the consumer perspective, such goods are problematic as they typically fail to meet the quality standards of genuine products. In the worst case scenario, they also pose specific human and environmental risks, including fire hazards, transit risks (for example in the case of substandard equipment for transport vehicles) and uncertain contents in products that are eaten or applied to the body.

The illicit trade in medicines, agrochemicals and consumer goods all impact economies directly by depriving states of tax revenues. Legitimate businesses are also deprived of revenues due to unfair competition from cheaper substandard products. This hurts both the development of local industry, as well as the export revenues of foreign companies. The proportion of counterfeit, pirated and substandard goods in selected categories of goods would need to be calculated to estimate these losses and such quantification (or estimates) do not exist in most sectors. Furthermore, illicit trade undermines the willingness and capacity of legitimate economic operators to invest in the economy, impacting growth and job creation.

In Ghana, the large scale of the illicit market for substandard and counterfeit medicines creates huge tax losses for the government. According to a Ghanaian government agency, such medicine is largely undeclared or falsely declared when it is imported or smuggled into the country. This deprives the state of revenue that would be due on genuine, registered pharmaceutical imports (GHA-Gov-110615). Based on controls of retailers by the FDA of Ghana, counterfeit medicines are most commonly sold without receipts and formal bookkeeping (GHA-Gov-Drug-090615). Tax revenues are thus also lost at the point of retail. Moreover, the public health impact of substandard medicine also has economic consequences, reducing productivity, adding patient treatment costs, and impacting the overall economic output of the country.

The illicit trade in agrochemicals also impacts the economy of Ghana in a number of ways. For example, such agrochemicals can reduce crop yields due to being ineffective or having inappropriate contents. Also, the extensive use of unapproved agrochemicals risks contamination of export crops. The positive reputation of Ghanaian cocoa is largely the result of an effective quality control system (GHA-Corp-Agri090515), but if significant quantities of exports were discovered to be contaminated, this could create negative reputational risks for the industry and compromise buyer willingness to purchase cocoa from Ghana in general. It could also have a negative impact on its price.

The theft or diversion of government-procured fertiliser and agrochemicals reduce the cost effectiveness of subsidy programmes. CODAPEC's "not for sale" products are often diverted. Large quantities have been 
found in other countries, including Nigeria, Côte d'Ivoire and even as far away as Cameroon (GHA-CorpAgri-120615). Such products also result in counterfeiters selling counterfeits as if they were diverted legitimate products.

Although counterfeit and unapproved medicines are frequently smuggled into Ghana or falsely declared, the larger volume of counterfeit consumer goods has received less focus. An international law enforcement agency representative believed most imports into Ghana pay some duty (GHA-Gov-LE-290515 \& 100615). This could be one explanation for the apparent lack of government concern about the problem. Yet interviewed Ghanaian officials and a counterfeit study by the EU Commission seem to contradict this, indicating that the trade in counterfeits consumer goods results in substantial tax revenue losses (Dunphy, 2008; GHA-Gov-LE-120615; GHA-Gov-110615). It would thus appear likely that significant tax losses are likely incurred even if these goods sometimes generate tax revenue on their sale.

Finally, price differences between states create economic incentives for illicit cross-border trade and further fuels its deleterious economic impacts. As previously mentioned, the Ghanaian Cocoa Board's Cocoa Disease and Pest Control Programme (CODAPEC) acquires vast quantities of products to be provided free to cocoa farmers. Opportunities for corruption exist both in the procurement process itself and in the diversion of agrochemicals from their intended beneficiaries (farmers). CODAPEC products can be sold instead of being distributed, and at prices below the market price for equivalent legitimate products.

\section{Complementarities with other crimes}

Corruption fuels the illicit trade in counterfeit, pirated and substandard goods, and the income generated by these activities contributes to a vicious cycle by helping to sustain a corrupt system, which in turn enables illicit activities.

The problem of corruption generated by illicit trade and the establishment of large-scale smuggling routes is not necessarily limited to commodities around which these smuggling routes originated. Smuggling routes across the Sahel, originally used for subsidised foodstuffs and consumer goods such as cigarettes, are also used for narcotics. Criminals, non-state armed actors and violent Islamist extremist groups in the region all profit from the illicit trade on such routes (FCO, 2013). Law enforcement representatives interviewed in Ghana had no concrete evidence that actors involved in illicit trade in goods that displace normally illicit goods were also involved in other crimes traditionally seen as more serious, such as narcotics or arms trafficking. But one Nigeria-based analyst stated that Nigerian criminals in 419 scams and the narcotics trade had laundered money through trade in counterfeit commodities in Ghana ${ }^{15}$ The same source stated that the transfer of profits abroad circumvents foreign currency controls (GHA-Gov110615).

The FIC of Ghana also observed that persons involved in illicit activities smuggle foreign currency out of the country, and use the formal banking system to transfer profits from the trade in counterfeit goods out of the country, through bank transfers. Frequently, false documentation is used to enable the transactions, and the companies used to facilitate these transactions (bank wires), exist only briefly. The second most common way to move illicit gains out of the country, according to the FIC, is by physically smuggling cash. A third method is withdrawals from Ghanaian bank accounts using credit cards abroad (GHA-Gov-110615). Some types of corrupt payments, such as those made by international suppliers to corrupt officials, may be conducted entirely outside the country. The police lack insight into the proportion of illicit proceeds that remain in Ghana or are transferred abroad (GHA-Gov-LE-120615). 


\section{Local problems with global implications}

States with weak enforcement capacities and endemic corruption are exposed directly to the risk of illicit trade, and then in turn also expose the broader global community to indirect risk.

According to the European Commission's 2013 Report on Customs and Intellectual Property Rights (IPR), goods shipped from Ghana represented almost $2 \%$ of EU interdictions of goods suspected of infringing IPR. This was due to large shipments of irregular batteries (European Union, 2014). Ghana has already served as a trans-shipment hub for counterfeits and illicit goods intended for West Africa. But it has also served as a trans-shipment point for markets further afield, including OECD member countries. Illicit shipments of many sorts, including counterfeits, frequently use indirect routes to reduce the likelihood of inspection. In certain contexts, Ghana may appear to be a less suspicious point of origin. 


\section{Concluding remarks}

The growth in global trade flows has increasingly exposed developing countries to illicit counterfeit, pirated and substandard goods. Experts, as well as government and private sector representatives interviewed for this case study, agree that more resources are needed to detect and prevent illicit trade in substandard goods and intellectual property crimes. Prosecuting such crimes also needs to be given higher priority.

Law enforcement representatives point to a system in which wealthy and corrupt businessmen are influential in elite circles, and enjoy a degree of insulation from the force of the law. This is driven by the financial patronage afforded to politicians, religious congregations and tribal leaders. Senior Ghanaian law enforcement officials state that when structuring corruption policy responses for Ghana, international donors need to take this wider perspective into account (GHA-Gov-110615; GHA-Gov-LE-110615; GHAGov-LE-290515 \& 100615). International donors and organisations can assist to incentivise anti-corruption efforts by ensuring, for example, that bilateral and multilateral aid is linked to results, such as reforms of policies that enable illicit trade. Ultimately, however, long-term success depends upon the commitment and determination of the political leadership in the country.

The policy considerations that follow constitute selected areas of reform that may be relevant for more than one category of goods. These policy considerations, which relate principally to questions of economic governance, should be further developed and carefully calibrated to local contexts to ensure feasibility and relevance. These are tabled for initial consideration only. Although reference is principally made to the application of these measures in the Ghanaian context, these policy considerations may also be relevant in other West African countries.

In the field of intellectual property rights, the role of right-holders is central. Consequently, effective publicprivate co-operation will play an important role in the attainment of successful outcomes.

\section{Quantifying the scale and impact of illicit trade}

Quantifying the scale and impact of any problem is needed to get the attention of policy makers and adequately target and formulate policy responses. There is still a dearth of data on illicit trade in counterfeit, pirated and substandard goods. With international assistance, more information on this issue could be garnered. International assistance, for example, is supporting the systemic testing of select major categories of drugs. This will contribute to better understanding the scale and nature of the problem of the illicit trade in medicines in West Africa, as elsewhere. Private co-operation could also play a useful role in combining the resources and expertise of the state and business to quantify the prevalence of illicit goods in various sectors.

Rendering donor support for further monitoring and quality control testing conditional upon public disclosure of the collected data would be helpful. Some data on medical treatment failure exists in the area of maternal and child health, for example, but there is significant room to gather more data on treatment failure linked to substandard medication (GHA-Gov-Pharm-100615), cover more sectors and more systematically share and publicise data. 


\section{Economic governance}

\section{Legally mandating product authentication}

Improve and enforce product authentication. Product authentication does not provide a magic solution or fix the shortcomings within the regulatory system itself but it can empower individual consumers to protect themselves by verifying whether a medication, agrochemical or consumer good is authentic (CAD-Analyst220615). Such solutions are already in use in various sectors. To maximise the effectiveness of such solutions, authorities could make their use mandatory, although if mandatory authentication were to be introduced, Ghana would need to ensure the procurement process is transparent and fair. Technical solutions for authenticating goods could also be promoted as a way forward by the Ghanaian authorities.

\section{Monitoring and enforcement across the medical supply chain}

The legal framework of Ghana is widely seen as robust, and improving legislation is just one step towards addressing the illicit trade in counterfeits. ${ }^{16}$ The Public Health Act, for example, imposes harsh prison sentences for illicit trade in medicines. Likewise, in the area of agrochemicals, representatives from the private sector consider current legislation to be relatively good. The problem often lies with enforcement of legislation already in place (GHA-Corp-Agri-120615; GHA-Corp-Agri-090515).

Effective enforcement of intellectual property rights is inherently challenging - a problem by no means limited to Ghana and West Africa. In Ghana, trade-mark owners bringing counterfeiting cases to the police frequently drop the cases and settle for compensation. Consequently, there is little punitive deterrence (GHA-Gov-LE-120615). Inefficiencies in the legal system, as well as legal expenses, may incite trade-mark owners to agree on a settlement rather than pursue criminal cases. For a leading Ghanaian business organisation, the fines and punishments for counterfeiters are too low in relation to the profits (GHA-Corp-Finance-200915).

Improve monitoring and enforcement across the medical supply chain. A plan to redesign medical supply chains, the Supply Chain Master Plan (SCMP), was adopted in 2012 to mitigate risks. The plan addresses shortcomings and forces government ministries and politicians to focus on the issue, with proposed improvements in the pre-evaluation of suppliers and post-market surveillance, as well as requirements to provide product authentication (GHA-Gov-Pharm-100615). The plan was initially slated for implementation in 2012 to 2017 but due to delays in implementation the SCMP was revised to cover the period 2015-2020. As a result, several key milestones are yet to be achieved, such as last mile distribution, logistics information systems, and the establishment of transparent and fair contracting frameworks.

Private sector critics have signalled that a number of previous initiatives generated few real improvements despite government rhetoric (GHA-Gov-LE-290515 \& 100615; GHA-Corp-Agri-1000615).

Most of the international community has shown a tendency to focus on form rather than substance, particularly on ensuring legislative changes, and the number of actual criminal convictions remains low despite the large scale and serious nature of the problem. Success depends on targeting the entire supply chain, including high-level organisers such as importers and global suppliers. ${ }^{17}$ Convictions have little effect if only street dealers are targeted. Corrupt facilitators within the government must also be prosecuted.

\section{Effectively appraising trade subsidy regimes}

Re-evaluate the agrochemical subsidy programme. Subsidies can influence the economic drivers related to illicit trade, serving both as deterrents and incentives to illicit trade. Examples of incentives include the Cocoa Board's agrochemical subsidy programme, which creates the economic preconditions for illicit flows of subsidised "not for sale" products across Ghana's borders ${ }^{18}$ and Algerian-subsidised food 
products, which are being smuggled across the Sahel into West Africa, where equivalent food subsidies are not in place (OECD, 2013). The World Bank also supports phasing out such subsidy programmes (GHA-IO-Econ-180615). It argues it is more effective to pay farmers more for cocoa so they can buy needed agrochemicals themselves. National governments may thus consider phasing out subsidy programmes.

Artificially low price goods can potentially deter certain forms of illicit trade, as in the case of subsidised medicines. Low-cost medication reduces the profit incentive for criminals to trade in illicit counterfeit or unregistered medication, which is more likely to be substandard, although few see the provision of low-cost medication as a panacea. It depends on financial support, which cannot be guaranteed to continue. If financial support for medication were to cease, prices would increase, potentially increasing the attractiveness for consumers, used to lower prices, of buying cheaper illicit products.

\section{Managing the role of intermediaries}

Encourage businesses and governments, both in Ghana and the region, to extend commitments to international standards around consumer protection. ${ }^{19}$ Both inside and outside the region, legitimate economic actors enable producers, traders and customers to engage in illicit trade. ${ }^{20}$ The $^{2}$ International Chamber of Commerce has published a number of good practices regarding intermediaries (International Chamber of Commerce, 2015b), and recommendations regarding legislation and governance of Free Trade Zones (International Chamber of Commerce, 2013), which could serve to introduce good practices. Additional guidelines that could be explored include UN Guidelines for Consumer Protection, as recommended by the International Chamber of Commerce's Business Action to Stop Counterfeiting and Piracy, and the standards set out by international consumer protection agencies, including the International Consumer Product Safety Caucus (ICPSC), International Consumer Product Safety and Health Organization (ICPSHO), and the OECD and its Consumer Policy Committee.

\section{Trade-based money laundering}

Expand the focus of anti-money laundering activities to capture this form of illicit trade, and complement it with broader anti-money laundering measures. Political leaders around the world have made it a priority to prevent money laundering used to finance terrorism, and significant law enforcement activity has been dedicated to tackling global narcotics flows. The illicit trade in counterfeit, pirated and substandard goods that replace normally legal goods has received relatively less political and law enforcement attention, as confirmed in interviews with officials in Ghana.

Considering the extent of this illicit trade in Ghana and West Africa more broadly, it would make sense to broaden and increase the focus of anti-money laundering activities relating to this form of illicit trade, and to complement it with broader anti-money laundering measures. Such efforts could include reducing the use of foreign currency in trade (especially that of US dollars, which is the most common currency illicitly transferred out of the country) inside Ghana, enhanced monitoring and inspection of banks and foreign exchange bureaus (resulting in fines for transgressions), and prosecution of individuals for breaches of money-laundering legislation.

\section{Regulatory standards and agreements}

States that profit from producing low-quality medications have effectively undermined international efforts to address substandard drugs, yet, West African states lack the regulatory and enforcement capacity to maintain the integrity of their supply chains. China, the world's largest economy in terms of purchasing power parity, is a primary source country for counterfeits (OECD, 2016), 
and it could assume greater responsibility in ensuring that its commercial actors comply with the law. China, however, is not the only culprit. As illicit trade in counterfeit, pirated and substandard goods is a consequence of global flows, the solution needs to be global in scope.

The integrity of supply chains could be enhanced by donors and international organisations, and by national administrations, through respectively the adoption of and compliance with a set of regulatory standards and by considering pursuing Customs Mutual Administrative Agreements with significant trade partners.

One proposed solution could be a global treaty framework (Attaran et al., 2012). According to Attaran, globalisation and trade liberalisation have taken place without a corresponding development of international criminal law or an international regulatory framework for medicines, therefore accounting for the high prevalence of substandard medicines in West Africa (and elsewhere).$^{21}$ There is a growing need to bind participating states to comply with set regulatory standards, where non-complying states could be prevented from exporting medicines. This could act as an incentive for middle-income states manufacturing low cost (and potentially low quality) drugs to comply with certain quality commitments, and would shift the onus of compliance from importing states to exporters.

A more limited approach would be to pursue Customs Mutual Administrative Agreements with significant trading partners that have not yet implemented such arrangements with Ghana. Such co-operation agreements could help customs authorities to make use of these new instruments. They could also help authorities to increase efficiency of existing tools to control trade flows to reduce fraud and illegal activities. 


\section{Annex A. Methodology}

In terms of methodology, the data in this case study draws upon three pillars: desk research, interviews, and surveys of consumers and retailers. Due to the limited systematic analysis of some forms of illicit trade covered, the text also cites news sources. Over 20 interviews with a range of sources from law enforcement, non-governmental organisations (NGOs), the public sector and international organisations were conducted. A complete interview list is available at the end of the paper. Most interviews took place during a field visit to Ghana in 2015. The Customs Division of the Ghana Revenue Authority did not make available customs seizure data, which could have added further insights regarding illicit trade.

A small-scale market survey targeting consumer and retailer perceptions relating to counterfeit goods within the pharmaceutical, agrochemical and consumer goods sectors was also conducted during May and June, 2015. The market research firm Vibrand Research interviewed 221 businesses selling agrochemicals (70), consumer goods (70) and pharmaceuticals (71), and 314 consumers. Geographically, the sampling was predominantly in Accra. This may understate the extent of the counterfeiting problem on a national basis. Illicit trade in pharmaceuticals and agrochemicals appears more extensive in more remote parts of the country. Greater sampling size and greater geographical spread would have been desirable, but were not possible due to limited resources. 


\section{References}

Adegoke, T. (6 August 2014), "Nigeria lost over a million jobs to counterfeiting in textile industry - SON", WorldStage Newsinline, http://worldstagegroup.com/index.php?active=news\&newscid=17131\&catid=30.

African Development Bank (2010), Ghana: 2010 Update of the 2005 - 2009 Country Strategy Paper and Request to Extend Validity until 2011, African Development Bank, Abidjan.

AllAfrica (27 November 2014), "Ghana: Minority want cocaine saga probed”, AllAfrica, http://allafrica.com/stories/201411271592.html.

Attaran, A. et al. (2012), "How to achieve international action on falsified and substandard medicines", BMJ, 24 November, Vol. 345, pp. 23-26, http://dx.doi.org/10.1136/bmj.e7381.

Bax, P. (11 June 2015), "Filth swamps Ghana capital in floods as regular as rains", Bloomberg Business, www.bloomberg.com/news/articles/2015-06-11/filth-swamps-ghana-capital-in-floods-as-regular-asrainy-season.

Bekoe, S.O. et al. (2014), "Determination of thirteen antibiotics in drug products - A new LC-MS/MS tool for screening drug product quality", Analytical Methods, Vol. 6/15, Royal Society of Chemistry, London, pp. 5847-5855.

Bruce-Amartey Jr., E., E.R.K. Amissah and K. Safo-Ankama (2014), "The decline of Ghana's textile industry: Its effects on textile education in Ghana", Arts and Design Studies, Vol. 22, International Knowledge Sharing Platform, pp. 36-44.

Citi FM Online (19 May 2015), "Fraudulent importers cost Ghana GH $\phi 36$ billion annually", Citi FM Online, http://citifmonline.com/2015/05/19/fraudulent-importers-cost-ghana-gh\%C2\%A236-billion-annually/.

CLDP (2010), "Ghana IP Advocacy and Outreach Program: Say No To Fake Goods, Insist on the Original”, webpage, http://cldp.doc.gov/programs/cldp-in-action/details/205 (accessed 1 November 2015).

Darko, S. (30 September 2015), "Ghana's anti-corruption blockbuster film draws crowds", BBC, www.bbc.com/news/world-africa-34383397.

Davreux, C. (2012), "The problem of counterfeit and illegal pesticides in Africa Middle East", presentation at the pesticide stewardship alliance conference, Boise, 8 February 2012,

http://tpsalliance.org/pdf/conference/2012/The\%20problem\%20of\%20lllegal\%20and\%20counterfeit\% 20Pesticides\%20in\%20Africa\%20Middle\%20East.pdf.

Dionne, K.Y. (15 July 2014), "Why West African governments are struggling in response to Ebola", Washington Post blog, www.washingtonpost.com/blogs/monkey-cage/wp/2014/07/15/why-westafrican-governments-are-struggling-in-response-to-ebola/.

Dunphy, T. (2008), An Assessment of the Social and Economic Causes and Impacts of Counterfeiting and Piracy in Ghana: An Analysis of Consumer and Industry Survey Findings, ACP Business Climate, 
Brussels.

Egbo, H. (2013), Quality Evaluation of a Selection of Antibiotics Distributed in Accra (Ghana) and Lagos (Nigeria), University of Ghana, Accra.

European Union (2014), Report on EU Customs Enforcement of Intellectual Property Rights: Results at the EU border, 2013, Publications Office of the European Union, Luxembourg.

FCO (2013), Traffickers and Terrorists: Drugs and Violent Jihad in Mali and the Wider Sahel, United Kingdom Foreign and Commonwealth Office, London.

Folkhälsomyndigheten (2014), Tuberkulos. Folkhälsomyndigheten webpage, www.folkhalsomyndigheten.se/amnesomraden/statistik-ochundersokningar/sjukdomsstatistik/tuberkulos/?t=com\&p=6108 (accessed 15 July 2015).

Food Standards Agency (2015), Foodstuffs with Current European Union (EU) restrictions (updated July 2015), www.food.gov.uk/sites/default/files/foodstuffs-with-current-EU-restrictions.pdf (accessed 20 September 2015).

Frontier Economics (2011), Estimating the Global Economic and Social Impacts of Counterfeiting and Piracy, Frontier Economics, London.

Ghana Armed Forces (2013), "Ghana sends troops to Mali", webpage, www.gaf.mil.gh/index.php?option=com_content\&view=article\&id=478:ghana-sends-troops-tomali\&catid=13:news\&ltemid=34 (accessed 15 July 2015).

Ghana Business News (8 February 2013), "Substandard Chinese medicines hit Ghanaian market", Ghana Business News, www.ghanabusinessnews.com/2013/02/08/substandard-chinese-medicineshit-ghanaian-market/.

Ghana News Agency (29 April 2010), "Ghana risks losing revenue through smuggling of alcoholic beverages”, Ghana News Agency, www.ghananewsagency.org/social/ghana-risks-losing-revenuethrough-smuggling-of-alcoholic-beverages-14991.

Ghanaian Ministry of Food and Agriculture (n.d.), "Plant Protection and Regulatory Services", webpage, http://mofa.gov.gh/site/?page_id=85 (accessed 15 July 2015).

GhanaWeb (3 December 2013a), "Fake condom importer unmasked!", GhanaWeb, www.ghanaweb.com/GhanaHomePage/NewsArchive/artikel.php?ID=294089.

GhanaWeb (19 April 2013b), "Fuel smuggling lucrative in Bawku", GhanaWeb, www.ghanaweb.com/GhanaHomePage/NewsArchive/Fuel-smuggling-lucrative-in-Bawku-271580.

GhanaWeb (23 October 2013c), "Ghana's cocoa faces ban", GhanaWeb, www.ghanaweb.com/GhanaHomePage/NewsArchive/artikel.php?ID=289686.

GhanaWeb (18 October 2013d), "Health ministry imports US\$6 million fake condoms", GhanaWeb, www.ghanaweb.com/GhanaHomePage/NewsArchive/Health-Ministry-imports-US-6-million-fakecondoms-289186.

GhanaWeb (29 April 2010), "Ghana risks losing revenue through smuggling of alcoholic beveragesFABAG”, GhanaWeb, www.ghanaweb.com/GhanaHomePage/NewsArchive/Ghana-risks-losingrevenue-through-smuggling-of-alcoholic-beverages-FABAG-181044.

Global Fund (n.d.), "Quality Assurance of Pharmaceutical Products", webpage, www.theglobalfund.org/en/healthproducts/qualityassurance/pharmaceutical/\#! (accessed 15 July 2015).

Global Initiative against Transnational Organized Crime (30 September 2014), "The world trade system must arm itself to fight illicit trade", Analyzing Organized Crime blog, www.globalinitiative.net/theworld-trade-system-must-arm-itself-to-fight-illicit-trade/.

Global Petrol Prices (2015), "Gasoline prices, liter”, GlobalPetrolPrices.com (database), 
www.globalpetrolprices.com/gasoline_prices/(accessed 15 July 2015).

The Guardian (14 July 2013), "Boko Haram leader calls for more schools attacks after dorm killings", The Guardian, www.theguardian.com/world/2013/jul/14/boko-haram-school-attacks-nigeria.

Guilford, G. (19 April 2013), "110 million fake condoms in Ghana: China's latest counterfeit scare", The Atlantic, www.theatlantic.com/china/archive/2013/04/110-million-fake-condoms-in-ghana-chinaslatest-counterfeit-scare/275144/.

IFPMA (2014), The Pharmaceutical Industry and Global Health: Facts and Figures 2014, International Federation of Pharmaceutical Manufacturers and Associations, Geneva.

Indian Press Information Bureau (2013), Survey on Spurious/Substandard Drugs. Joy Online (3 December 2014), "Kennedy Agyapong, Alhaji Bature trade insults over cocaine Angel", My Joy Online, www.myjoyonline.com/politics/2014/december-3rd/kennedy-agyapongalhaji-bature-tradeinsults-over-cocaine-angel.php.

International Chamber of Commerce (2015a), "CACIT Ghana", webpage, www.iccwbo.org/advocacycodes-and-rules/bascap/bascap-gateways/connections-gateway/cacit-ghana/ (accessed 1 November 2015).

International Chamber of Commerce (2015b), Roles and Responsibilities of Intermediaries: Fighting Counterfeiting and Piracy in the Supply Chain, International Chamber of Commerce, Paris, www.iccwbo.org/Advocacy-Codes-and-Rules/BASCAP/International-engagement-andAdvocacy/Roles-and-Responsibilities-of-Intermediaries/.

International Chamber of Commerce (2013), Controlling the Zone: Balancing Facilitation and Control to Combat Illicit Trade in the World's Free Trade Zones, International Chamber of Commerce, Paris, www.iccwbo.org/advocacy-codes-and-rules/bascap/international-engagement-and-advocacy/freetrade-zones/.

Karikari-Boateng, E. (2012), Post-Market Quality Surveillance Project: Maternal Healthcare Products (Oxytocin and Ergometrine) on the Ghanaian Market: Report of First Round, United States Agency for International Development, Washington, D.C.

Kpodo, K. (3 June 2015), "Ghana to scrap fuel subsidies by Sept - oil minister", Reuters, www.reuters.com/article/2015/06/03/ghana-subsidies-idUSL5N0YP4S320150603.

Laary, D. (15 January 2015a), "Ghana: Medical supplies estimated at $\phi 237$ million lost to fire", The Africa Report, www.theafricareport.com/West-Africa/ghana-medical-supplies-estimated-at-c237-million-lostto-fire.html.

Laary, D. (3 July 2015b), "Ghana-China trade surpasses $\$ 5$ billion”, The Africa Report, www.theafricareport.com/West-Africa/ghanas-china-trade-surpasses-5-billion.html.

Lallerstedt, K. and P. Krassén (2015), How Leading Companies are affected by Counterfeiting and IP Infringement - A study of the NASDAQ OMX 30 Stockholm Index, Black Market Watch and Svenskt Näringsliv, Geneva and Stockholm.

Laven A. and M. Boomsma (2012), Incentives for Sustainable Cocoa Production in Ghana, Moving from Maximizing Outputs to Optimizing Performance, Royal Tropical Institute, Amsterdam, http://worldcocoafoundation.org/wp-content/files_mf/laven201297.pdf.

Ncube, C. (2 June 2014), "IP policies in Africa no. 22: Ghana” Afro-IP blog, http://afroip.blogspot.se/2014/06/ip-policies-in-africa-no-22-ghana.html.

OECD (n.d.), "Ghana”, webpage, https://atlas.media.mit.edu/en/profile/country/gha/ (accessed 15 July 2015).

OECD (2016), Trade in Counterfeit and Pirated Goods: Mapping the Economic Impact, OECD Publishing, Paris. 
OECD/EUIPO (2019), Trends in Trade in Counterfeit and Pirated Goods, Illicit Trade, OECD Publishing, Paris, https://doi.org/10.1787/g2g9f533-en.

OECD (2013), West African Futures: Settlement, Market and Food Security, OECD Publishing, Paris.

Osei-Boateng, C. and E. Ampratwum (2011), The Informal Sector in Ghana, Friedrich Ebert Stiftung, Ghana Office, http://library.fes.de/pdf-files/bueros/ghana/10496.pdf.

Osei-Safo, D. et al. (2014). "Evaluation of the quality of artemisinin-based antimalarial medicines distributed in Ghana and Togo", Malaria Research and Treatment, 27 October, Vol. 2014, pp. 1-12, http://dx.doi.org/10.1155/2014/806416.

Parliament of Ghana (2012), Ghanaian Public Health Act, 2012, Parliament of the Republic of Ghana, Accra.

PM News (20 September 2013), "Igbos, other Africans making it big in China", PM News Nigeria, www.pmnewsnigeria.com/2013/09/20/igbos-other-africans-making-it-big-in-china/.

Public Procurement Authority (2003), The Public Procurement Act, 2003, The Public Procurement Authority, http://www.ppaghana.org/documents/Public\%20Procurement\%20Act\%202003\%20Act\%20663.pdf.

Saana Consulting (2013), Factual Overview on Technical and Financial Cooperation for LDCs related to the TRIPS Agreement: Identifying and Responding to Individual Priority Needs Of LDCs, Saana Consulting, London.

Savona E. and M. Riccardi (eds.) (2015), From Illegal Markets to Legitimate Businesses: The Portfolio of Organised Crime in Europe, Trento, Transcrime, Università degli Studi di Trento, www.ocportfolio.eu/_File\%20originali/OCP\%20Full\%20Report.pdf.

Solsvik, T. and O.P. Skonnord (15 January 2014), "Update 2-Norway's Yara fined $\$ 48 \mathrm{mln}$ after crossborder bribery probe", Reuters, www.reuters.com/article/2014/01/15/yara-briberyidUSL5N0KP0R520140115.

Stanton, C. et al. (2012), "Uterotonic drug quality: An assessment of the potency of injectable uterotonic drugs purchased by simulated clients in three districts in Ghana", BMJ Open, 3 May, Vol. 2/3, http://dx.doi.org/ 10.1136/bmjopen-2011-000431.

State Council of the People's Republic of China (2015), Key Tasks on Cracking Down on Infringement and Counterfeiting website, http://www.gov.cn/zhengce/content/2015-04/09/content_9585.htm (accessed 9 April 2016).

Thiénot, D. (19 February 2013), "Au Mali, les djihadistes se droguent à la kétamine", L'express France, www.lexpress.fr/actualite/monde/afrique/au-mali-les-djihadistes-se-droguent-a-la-

ketamine_1222326.html

UNODC (2014), Current Situation with Respect to Subregional and Regional Cooperation in Countering Drug Trafficking, United Nations Office on Drugs and Crime, Vienna.

UNODC (2006), 2005 World Drug Report, United Nations Office on Drugs and Crime, Vienna.

United States Pharmacopeial Convention (2015), Medicines Quality Database, www.usp.org/globalhealth-programs/promoting-quality-medicines-pqmusaid/medicines-quality-database-mqdb (accessed 15 July 2015).

Vibrand Research (2015), Counterfeit Study Ghana, Vibrand Research, Cape Town.

WCO (2013), Illicit Trade Report 2013, World Customs Organization, Brussels.

WHO (2014), World Health Statistics 2014, World Health Organization, Geneva.

WHO (2012), Medicines: Spurious/Falsely-labeled/Falsified/counterfeit (SFFC) Medicines, World Health

Organization, Geneva. 
WHO (2011), Survey of the Quality of Selected Antimalarial Medicines Circulating in Six Countries of Sub-Saharan Africa, World Health Organization, Geneva.

WTO, StatisticalProgram (2018) http://stat.wto.org/StatisticalProgram/WSDBViewData.aspx?Language $=\mathrm{E}$

World Bank (2015a), "Employment in agriculture (percentage of total employment)", in World Development Indicators (database), World Bank, Washington, D.C., http://data.worldbank.org/indicator/SL.AGR.EMPL.ZS (accessed 15 July 2015).

World Bank (2015b), "GDP (current US\$)", in World Development Indicators (database), World Bank, Washington, D.C., http://data.worldbank.org/indicator/NY.GDP.MKTP.CD (accessed 15 July 2015).

World Bank (2012), Agribusiness Indicators: Ghana, World Bank, Washington, D.C.

World Cocoa Foundation (2012), Cocoa Market Update, World Cocoa Foundation, Washington, D.C.

\section{Interviews}

CAD-Analyst-220615, Professor of Law and Population Health, International University, Canada, 22 June 2015.

GHA-Corp-Agri-120615, Programme Manager, Business Association in Ghana, 12 June 2015.

GHA-Corp-Agri-1000615, Corporate Affairs Manager, Company Providing Product Integrity Solutions (Ghana), 10 June 2015.

GHA-Corp-Agri-090515, Technical Advisor, Industry Association (Ghana Office), 9 June 2015.

GHA-Corp-Finance-200915, Secretary General, Business Association in Ghana, 20 September 2015.

GHA-Corp-Pharma-120615, Deputy-Director, Government Agency (Ghana), 12 June 2015.

GHA-Gov-090615, Chief Executive, Government Authority in Ghana, 9 June 2015.

GHA-Gov-110615, Chief Executive and Head of Research, Government Agency (Ghana), 11 June 2015.

GHA-Gov-Drug-090616, Government Official (Drugs), Government Authority in Ghana, 9 June 2016.

GHA-Gov-Justice-100615, Senior Justice Representative, Government of Ghana, 10 June 2015.

GHA-Gov-LE-110615, Chief Executive, Government Law Enforcement Entity (Ghana), 11 June 2015.

GHA-Gov-LE-120615, Law Enforcement Officer, Law Enforcement Agency (Ghana), 12 June 2015.

GHA-Gov-LE-100615, Head of, Special Government Entity (Ghana), 10 June 2015.

GHA-Gov-LE-290515 \& 100615, Law Enforcement Officer, Foreign Embassy in Ghana, 29 May 2015 and 10 June 2015.

GHA-Gov-Pharm-100614, Director, Government Ministry (Ghana), 10 June 2015.

GHA-IO-Econ-180615, Economist, International Organisation (Ghana), 18 June 2015.

GHA-Journ-120615, Investigative Journalist, Media Organisation (Ghana), 12 June 2015.

GHA-INGO-Pharm-120615, Pharmaceutical Expert, International NGO (Ghana), 12 June 2015.

NGA-Analyst-250615, Senior Analyst, Consulting Firm (Nigeria), 25 June 2015.

NGA-Corp-Trade-030715, West Africa Anti-Illicit Trade Manager, Multinational Corporation (Nigeria), 3 July 2015.

NIG-Corp-Auto-120615, Automotive Industry Engineer, Multinational Corporation (International), 14 June 2015.

USA-Gov-Hum-190515, International Aid Expert, Government Aid Agency (International Aid Agency), 19 May 2015.

ILLICIT FINANCIAL FLOWS: ILLICIT TRADE IN COUNTERFEIT, PIRATED AND SUBSTANDARD GOODS IN GHANA ๑ OECD 2019 
VIE-UNODC-030515, Africa Crime Expert, International Organisation, 3 June 2015.

\section{Notes}

${ }^{1}$ Counterfeiting and piracy are terms used to describe a range of illicit activities related to intellectual property rights (IPR) infringement (see OECD (2016), p. 16), whilst substandard goods refer to goods the quality and characteristics of which fall below regulatory standards of a given country.

${ }^{2}$ The 2016 OECD report focuses primarily on the infringement of copyright, trademarks, design rights, and patents, as described in the World Trade Organisation Agreement on Trade-Related Aspects of Intellectual Property Rights (TRIPS Agreement). Consequently, it uses the term counterfeit to refer to tangible goods that infringe trademarks, design rights or patents, and pirated to refer to tangible goods that infringe copyright; and does not include intangible infringements, such as online piracy, nor infringements of other intellectual property rights.

${ }^{3}$ A 2015 study by Transcrime, commissioned by the European Commission, estimated that organised crime revenues in Europe from counterfeiting exceed those of narcotics (Savona and Riccardi, 2015).

${ }^{4}$ Ergometrine and oxytocin (frequently together) can be used in obstetrics to facilitate delivery of the placenta and to prevent bleeding after childbirth. Oxytocin can also be used to induce labour and in cases of slow childbirth.

${ }^{5}$ Due to the different forms of illicit pharmaceuticals available, and the imprecise application of terminology, responders may mean counterfeit specifically, or illicit non-authorised products more broadly.

6 There are no recent estimates on percentage employment in the informal sector by the International Labour Organization or the World Bank. In its 2010 "Ghana: 2010 update of the 2005 - 2009 country strategy paper" the African Development Bank stated: "The informal segment of the private sector provides employment and a source of livelihood to many low skilled Ghanaians accounting for about $91 \%$ of the employment generated by the private sector" (African Development Bank, 2010). In 2011, the Friedrich Erbert Stiftung's Ghana office published a report on the informal sector, stating it employed $80 \%$ of the workforce (Osei-Boateng and Ampratwum, 2011).

7 See information on illicit outflows of subsidised agrochemicals in the section on Counterfeit and non-approved agrochemicals in Nature and scope of illicit trade.

${ }^{8}$ Interlocutors from Ghana's police service, the Economic and Organised Crime Office, the FIC, the Ghana Standards Authority, the Presidential Special Operations Taskforce and international law enforcement agencies all stressed the problem of systemic corruption in Ghana. Ghana's score for Control of Corruption (World Bank Governance Indicators) has deteriorated. This measure captures perceptions of the extent to which public power is exercised for private gain, as well as state capture by elites and private interests, on a scale from -2.5 to 2.5 . In 2014 , it was calculated at -0.21 , with an apparent decline since 2010 when it was 0.06 .

${ }^{9}$ Ghana scored 48 out of 100 on the 2014 Transparency International Corruption Perception Index, where a lower score implies higher corruption. This is a better score than all other ECOWAS states, where the Corruption Perception Index suggests higher levels of corruption than in Ghana. On World Bank Governance Indicators 2014, Ghana scored -0.21 for control of corruption (on a scale where -2.5 is minimum and 2.5 maximum), again "better" than other ECOWAS states. As a reference, Nigeria scored -1.27. In September 2015, a Ghanaian investigative journalist released a documentary film, drawing on 500 hours of raw footage, alleging that 34 judges and dozens of court workers took bribes from litigants to manipulate justice (Darko, 2015).

10 For example, in religious congregations donations are actively sought from the wealthy members, who will consequently gain enhanced standing within that context.

${ }^{11}$ Research points out that subsidies on fertiliser are "not transparent. The decisions on fertiliser distribution and prices are highly political" (Laven and Boomsma, 2012). 
12 Corruption in public procurement implies both the involvement of public officials and private sector suppliers, local or international. The potential role of large international corporations in enabling public procurement corruption should not be overlooked.

${ }^{13}$ According to the Intellectual Property Offences Section of the Fraud Unit of the Ghana Police Service, most counterfeit cases deal with products originating in China (GHA-Gov-LE-120615; GHA-Gov-110615).

${ }^{14}$ Mandrax, a brand name of Methaqualone, also known as Quaaludes, is a sedative. Its abuse potential increases when combined with other drugs, such as alcohol or marijuana. South Africa is the world's largest market for Mandrax, and pills are commonly crushed and smoked together with marijuana.

15419 fraud schemes cover a broad range of activities. The "Nigeria letter" emails are perhaps the most commonly known example. The number 419 refers to the section of the Nigerian criminal code dealing with fraud.

${ }^{16}$ Although the legal regime is broadly comprehensive, there are still areas for improvement. For example, though several laws relate to counterfeit and substandard goods (such as those dealing with trademarks, standard compliance and smuggling), legal loopholes exist, i.e. no law specifically defines a counterfeit product, according to the Ghana Police Service. Also, certain counterfeit cases, such as sale of false electrical components, are considered misdemeanours. Potential risks to human safety (such as fire hazards) are not taken into account. To enhance the deterrent effect of legislation it might therefore be appropriate to review the country's relevant laws (GHA-Gov-LE120615).

17 The Global Fund has instituted a program to ensure quality pharmaceutical procurement, and this includes random quality control of finished products along the entire supply chain (Global Fund, n.d.). Aid agencies supporting procurement where counterfeit or substandard products could contaminate the supply chain could similarly dedicate funds to quality control. Quality control programmes, such as those supported by international aid agencies in the area of medical products, could also be implemented in other sectors, where counterfeit or substandard products are recurrent.

18 Note, the World Cocoa Foundation advocates (GHA-Corp-Agri-090515) the gradual phasing out of this subsidy programme, and further recommends encouraging private businesses that sell authorised products to develop stronger sales networks. In addition, technical solutions should be found for verifying the authenticity of products.

19 This would be consistent with the recommendations of the International Chamber of Commerce's Business Action to Stop Counterfeiting and Piracy.

20 These range from financial institutions that transfer payments, shipping firms transporting goods, suppliers who provide input to counterfeit, pirated or substandard products, and websites and search engines that facilitate access to counterfeit products on the Internet.

${ }^{21}$ Attaran also believes the Ghanaian FDA should not invest time and money in granting approval to drug importers. Rather, Ghana should expedite approval processes for imports from manufacturers that have already been approved by states with high regulatory standards (such as OECD member states). 


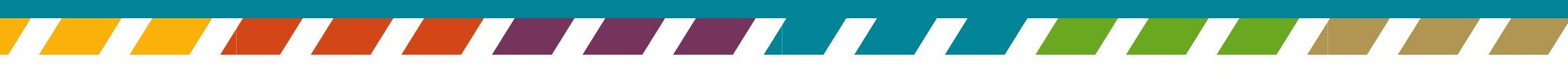

